\title{
ARTICLES
}

\section{Manipulative Marketing and the First Amendment}

\author{
MiCAH L. BERMAN*
}

"The First Amendment's concern for commercial speech is based on the informational function of advertising."

—Central Hudson Gas \& Electric v. Public Service Commission ${ }^{1}$

The conventional wisdom is that the Supreme Court's review of commercial speech restrictions has gradually become more stringent over time, edging further and further in the direction of strict scrutiny. What this narrative misses is that the Supreme Court's review has become more rigorous over time only for a certain type of commercial speech regulation: laws that restrict nonmisleading, informational advertising. A majority of the Court sees this type of regulation as unwarranted-indeed offensive-governmental paternalism. However; a careful reading of the Court's decisions suggests that it has been, and remains, far more willing to uphold regulations on commercial speech where the governmental purpose is not to keep information from consumers, but to protect consumers from manipulation.

The commercial speech doctrine is fundamentally based on the premise that advertising communicates information to consumers, allowing them to make more informed choices. However, many common advertising techniques do not rely on communicating information; instead, they use emotional and nonconscious marketing techniques to take advantage of consumers' cognitive limitations and biases. This Article argues that such noninformational marketing practices are entitled to limited, if any, protection under the First Amendment, particularly when the products or activities being promoted are harmful to public health.

After reviewing the history of the commercial speech doctrine, this Article explores the connection between marketing and cognitive psychology and provides several examples of "manipulative marketing." It concludes by analyzing possible doctrinal frameworks for the regulation of harmful and manipulative marketing practices.

\footnotetext{
* Assistant Professor of Public Health and Law, Ohio State University College of Public Health and Moritz College of Law. (C) 2015, Micah L. Berman. Thanks to the faculty of the University of Dayton School of Law and to the participants at the Big 10 Junior Scholars Workshop, the Ohio Legal Scholars Workshop, and the ASLME Health Law Professors' Conference for their helpful feedback on earlier versions of this Article. Special thanks to Chris Walker, Ted Mermin, and Tamara Piety for their constructive comments, as well as to all of the members of the George Project.
}

1. 447 U.S. 557,563 (1980). 


\section{TABLE OF CONTENTS}

INTRODUCTION

I. History of the Commercial Speech Doctrine $\ldots \ldots \ldots \ldots \ldots$. . . 502

A. THE ORIGINS OF THE COMMERCIAL SPEECH DOCTRINE . . . . . 503

B. EARLY COMMERCIAL SPEECH CASES: RESTRICTIONS ON MANIPULATIVE PRACTICES $\ldots \ldots \ldots \ldots \ldots \ldots$

C. CENTRAL HUDSON: A DOCTRINAL FRAMEWORK AT ODDS WITH

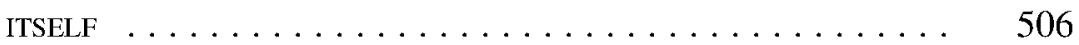

D. FROM CENTRAL HUDSON TO SORRELL: TOWARD STRICTER

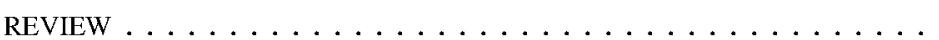

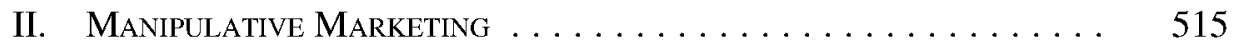

A. MODERN MARKETING AND THE COLLAPSE OF THE INFORMATIONAL

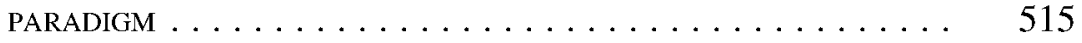

B. TARGETING THE SUBCONSCIOUS: NEUROMARKETING AND THE DUAL-PROCESSING MODEL OF DECISIONMAKING $\ldots \ldots \ldots \ldots$

1. Application of the Dual-Processing Model to

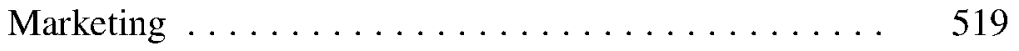

2. Defining Manipulative Marketing . . . . . . . 522

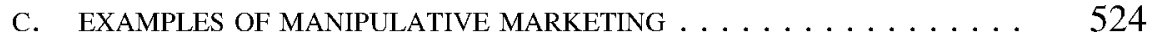

1. Product Placement $\ldots \ldots \ldots \ldots \ldots \ldots \ldots \ldots$

2. Packaging Color . . . . . . . . . . . . . . . 529

D. THE NONSOLUTION OF DISCLOSURE REQUIREMENTS . . . . . . . 533

III. Manipulative Marketing Meets the First Amendment . . . . . . 536

A. EXCLUDING MANIPULATIVE MARKETING FROM FIRST AMENDMENT PROTECTION .......................... 537

B. INTERMEDIATE SCRUTINY . . . . . . . . . . . . . . . . 541

1. To Qualify for First Amendment Protection, the Commercial Speech Must Concern Lawful Activity and Not Be Misleading . . . . . . . . . . . . . . . . . .

2. The Government's Asserted Interest in Restricting the Speech Must Be Substantial . . . . . . . . . . . 
3. The Restriction Must Directly Advance the Government's Asserted Interest $\ldots \ldots \ldots \ldots \ldots \ldots$

4. The Restriction Must Not Be More Extensive Than Necessary to Serve the Asserted Government Interest . .

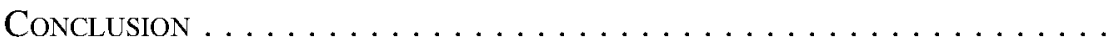

\section{INTRODUCTION}

The history of the Supreme Court's commercial speech doctrine is often seen as a linear trajectory. The conventional wisdom is that ever since the Court first decided in the mid-1970s that the First Amendment's protections extended to commercial speech, its review of commercial speech restrictions has gradually become more and more stringent over time. ${ }^{2}$ Today, the Supreme Court's commercial speech doctrine is deemed "an amalgam of strict scrutiny and intermediate scrutiny," leaning ever further in the direction of strict scrutiny. ${ }^{3}$ Many have speculated that the Supreme Court is on the verge of granting full First Amendment protection to commercial speech, eliminating the longstanding doctrinal distinction between commercial and noncommercial speech. ${ }^{4}$

This conventional narrative is correct-but only to a point. This narrative misses that the Supreme Court's review has become more rigorous over time, but only for a certain type of commercial speech regulation: laws that restrict nonmisleading, informational advertising. A majority of the current Court essentially subscribes to the view expressed by Justice Stevens in Rubin v. Coors Brewing Co.:

2. See, e.g., Paul Horwitz, Free Speech as Risk Analysis: Heuristics, Biases, and Institutions in the First Amendment, 76 Temp. L. Rev. 1, 49 (2003) ("[C]ommercial speech jurisprudence has moved steadily toward a speech-protective approach that has erased the distinction between commercial speech and other categories of speech."); Rodney A. Smolla, Afterword, Free the Fortune 500! The Debate over Corporate Speech and the First Amendment, 54 CASE W. REs. L. REv. 1277, 1292 (2004) ("While nominally the Supreme Court continues to apply the intermediate scrutiny standard of Central Hudson, examination of the actual case decisions demonstrates that the trajectory of modern commercial speech law has been an accelerating rise of protection for advertising."); Nat Stern \& Mark Joseph Stern, Advancing an Adaptive Standard of Strict Scrutiny for Content-Based Commercial Speech Regulation, 47 U. Rich. L. Rev. 1171, 1171 (2013) (discussing the "gradual elevation of commercial speech from 'its subordinate position in the scale of First Amendment values' to its status as a form of expression that routinely enjoys robust protection from the Court" (footnote omitted) (quoting Ohralik v. Ohio State Bar Ass'n, 436 U.S. 447, 456 (1978))).

3. Seth E. Mermin \& Samantha K. Graff, The First Amendment and Public Health, At Odds, 39 AM. J.L. \& MED. 298, 299 n.11 (2013).

4. See, e.g., Darrel C. Menthe, The Marketplace Metaphor and Commercial Speech Doctrine: Or How I Learned to Stop Worrying About and Love Citizens United, 38 Hastings Const. L.Q. 131, 133 (2010) (arguing that "Citizens United will necessarily lead to the abandonment of commercial speech doctrine as formulated in Central Hudson"); David C. Vladeck, Lessons from a Story Untold: Nike v. Kasky Reconsidered, 54 CASE W. RES. L. REV. 1049, 1052 (2004) ("Since 44 Liquormart, the Court has made it clear that it would be willing to revisit the [commercial speech] doctrine should the appropriate case come along."). 
Any "interest" in restricting the flow of accurate information because of the perceived danger of that knowledge is anathema to the First Amendment; more speech and a better informed citizenry are among the central goals of the Free Speech Clause. Accordingly, the Constitution is most skeptical of supposed state interests that seek to keep people in the dark for what the government believes to be their own good. ${ }^{5}$

In other words, laws that seek to deprive people of information for "their own good" constitute unwarranted-indeed "offensive"-governmental paternalism and presumptively violate the First Amendment. ${ }^{6}$ However, a careful reading of the Court's decisions suggests that it has been, and remains, far more willing to uphold regulations on commercial speech where the governmental purpose is not to keep information from consumers, but rather to protect the fairness of the commercial transaction by preventing consumers from being misled or manipulated.

The commercial speech doctrine is fundamentally based on the premises that advertising (1) communicates information to consumers, and (2) such information allows consumers to make autonomous and more informed choices. When these core assumptions underlying the commercial speech doctrine do not hold, that is, when advertising does not communicate any informational content and when the advertising either misleads or manipulates consumers, the case for First Amendment protection is considerably weaker. In such cases, regulation does not offend, and indeed may further, the interests animating the Court's commercial speech doctrine.

Many common advertising techniques do not rely on communicating information, as the Court's commercial speech cases assume that all advertising does. Instead, they seek to influence consumers at a subconscious or emotional level. Behavioral and neurological research over the last several decades suggests that subconscious cues can powerfully influence consumer choices, and this research provides the foundation for many modern marketing techniques. Marketers use such research to inform, among other things, "the layout of stores, the music playing in the background, and the lighting[,] ... logos, colors, displays, and the look of the product."7 All of these marketing practices are noninformational and are often not consciously perceived, yet they exert a significant influence on consumer decisionmaking. In many cases, the use of such promotional practices may be unproblematic. But when such marketing practices are used in ways that harm consumers, government regulation could be supported by the state's interest in protecting the fairness of consumer transactions, in addition to its traditional regulatory interests in protecting the health and welfare of the public.

\footnotetext{
5. Rubin v. Coors Brewing Co., 514 U.S. 476, 497 (1995) (Stevens, J., concurring in the judgment).

6. 44 Liquormart, Inc. v. Rhode Island, 517 U.S. 484, 503 (1996) (plurality opinion).

7. Tamara R. Piety, Brandishing the First Amendment: Commercial Expression in America 117 (2012).
} 
This Article examines the Supreme Court's assumption that advertising provides information and questions how the commercial speech doctrine should apply to modern marketing techniques. It demonstrates that noninformational marketing practices that manipulate consumers-and particularly marketing practices that seek to subconsciously influence consumer decisionmakingshould be entitled to limited, if any, protection under the First Amendment. When the governmental purpose in regulating commercial speech is to prevent marketers from manipulating consumer decisionmaking, there is a strong normative and doctrinal case that a court's review should be deferential. That case is particularly strong when the promotional tactic at issue threatens other important government interests such as public health, consumer safety, or environmental protection.

Accordingly, while the conventional wisdom is that few if any restrictions on commercial speech can survive First Amendment review, this Article identifies doctrinal space for robust regulation where the government can establish that the marketing at issue is manipulative. This is not to say that the government should regulate manipulative marketing in any particular case; rather, this Article argues only that the courts should recognize the constitutional authority of the government to regulate manipulative marketing practices should it choose to do so (with adequate evidentiary justification).

This Article proceeds in three Parts. Part I reconsiders the history of the Supreme Court's decisions relating to the regulation of commercial speech. This review suggests that although the Court has moved toward more stringent standards of review, it has left open the possibility that marketing practices that are manipulative - even if not technically false or misleading — are not entitled to the same level of protection as other commercial speech. While this conclusion follows directly from an analysis of the Supreme Court's cases, it has not yet been well developed in either case law or legal scholarship.

Part II discusses how modern marketing has moved away from an informational paradigm - the paradigm around which the commercial speech doctrine was constructed - toward marketing practices that emphasize emotional appeals. Not only is this marketing noninformational, but marketers today often seek to influence consumers' attitudes and opinions outside the sphere of conscious awareness. Businesses employing these practices are not acting with any malicious intent; instead they are responding to market pressures and even consumer preferences. (Many consumers may prefer subtler and less intrusive advertising to more direct, and annoying, forms.) Nonetheless, these marketing practices are manipulative, in the sense that they shape consumers' attitudes and preferences without their knowledge. Particularly when the products being advertised are themselves harmful - as in the case of "vice products" such as tobacco and alcohol - there may be a strong case for government regulation of these manipulative advertising techniques. This is true even if one concedes that the Supreme Court's cases sharply limit the government's ability to regulate the informational content of advertisements for such products. 
Finally, Part III connects the discussions in Part I and Part II by considering potential frameworks for reviewing restrictions on manipulative marketing. This Part suggests that methods of marketing can be restricted, consistent with the Supreme Court's current commercial speech doctrine, when the government can establish that the marketing at issue is both harmful and manipulative. Indeed, such restrictions advance the underlying rationales of the commercial speech doctrine by protecting the ability of consumers to make informed and autonomous purchasing decisions. The Article concludes by proposing a modified version of the Court's Central Hudson test as the appropriate doctrinal framework.

\section{History of the Commercial Speech Doctrine}

A careful examination of the Supreme Court's commercial speech doctrine reveals two key points. First, the doctrine is fundamentally premised on the informational value to consumers of commercial advertising. Although recent cases have paid somewhat less attention to consumers' interests, instead putting more weight on the asserted rights of the commercial speakers, ${ }^{8}$ the Court continues to ground its commercial speech doctrine in the informational value of such speech. Accordingly, the Court is highly skeptical of any regulation that seeks to deprive consumers of information (or prevent marketers from communicating information) in order to influence consumer behavior. This doctrinal focus on informational communication is increasingly divorced from the reality of modern advertising techniques that seek to engage potential customers on an emotional level, often deliberately eschewing the communication of any informational content whatsoever. ${ }^{9}$

Second, and relatedly, the Court's doctrine allows more flexibility when the government's goal is not to deprive consumers of information, but to protect the fairness of the consumer transaction. Though few Supreme Court cases are directly on point, the authority of legislatures to protect consumers from abuse or manipulation has been a consistent sub-theme in the dicta of the Court's commercial speech decisions. ${ }^{10}$ This second point suggests that there may be doctrinal room for regulating commercial speech if that speech manipulates the consumer, and especially if such manipulation contributes to societal harms.

\footnotetext{
8. Smolla, supra note 2, at 1295-96 (discussing a "paradigm shift that has taken place in commercial speech law, in which the focus has moved from consumer protection to speaker protection").

9. Yoav Hammer, Expressions Which Preclude Rational Processing: The Case for Regulating Non-Informational Advertisements, 27 WhitTiER L. REv. 435, 437 (2005) (writing that in modern advertising "[t]he messages come in mostly visual and non verbal form, and viewers are hardly aware of the fact that messages have been conveyed").

10. See, e.g., 44 Liquormart, 517 U.S. at 501 (plurality opinion) ("When a State regulates commercial messages to protect consumers from misleading, deceptive, or aggressive sales practices, or requires the disclosure of beneficial consumer information, the purpose of its regulation is consistent with the reasons for according constitutional protection to commercial speech and therefore justifies less than strict review.").
} 


\section{A. THE ORIGINS OF THE COMMERCIAL SPEECH DOCTRINE}

Before the mid-1970s, the Supreme Court did not consider commercial speech to be protected by the First Amendment at all. ${ }^{11}$ However, in a series of cases culminating in Virginia State Board of Pharmacy v. Virginia Citizens Consumer Council Inc. (Virginia Pharmacy), the Supreme Court changed course and decided that the First Amendment's protections extended to commercial speech. ${ }^{12}$

In Virginia Pharmacy, Public Citizen (a consumer protection nonprofit organization created by Ralph Nader) led the challenge to a Virginia law prohibiting the advertisement of pharmaceutical drug prices. The Court, in an opinion by Justice Blackmun, largely adopted Public Citizen's arguments and focused its reasoning on the protection of consumer interests. ${ }^{13}$ The Court offered three justifications for according commercial speech constitutional protection:

- The Consumer Interest Rationale: First, the Court wrote that a "consumer's interest in the free flow of commercial information... may be as keen, if not keener by far, than his interest in the day's most urgent political debate." 14 In the specific context of prescription drug prices, "the poor, the sick, and particularly the aged" have a pressing need for access to such information, as they can benefit from access to lowerpriced drugs but are least able to travel from pharmacist to pharmacist to compare prices. ${ }^{15}$

- The Market Efficiency Rationale: Second, because advertisements constitute "dissemination of information as to who is producing and selling what product, for what reason, and at what price," commercial speech can help ensure that consumer decisions are "intelligent and well informed." In the aggregate, this will help to ensure a more efficient economic marketplace. ${ }^{17}$

- The Public Interest Rationale: The Court's final justification was that "an individual advertisement, though entirely 'commercial,' may be of general public interest." 18 That is, advertisements may provide commentary on political issues of the day, for example, when "a manufacturer of

11. See Valentine v. Chrestensen, 316 U.S. 52, 54 (1942) ("We are equally clear that the Constitution imposes no such restraint on government as respects purely commercial advertising.").

12. 425 U.S. 748,762 (1976).

13. See Alan B. Morrison, How We Got the Commercial Speech Doctrine: An Originalist's Recollections, 54 CASE W. RES. L. REv. 1189, 1198 (2004) ("Justice Blackmun's opinion ... bought our argument based on the interests of those who would receive the information and relied on the evidence that we had amassed about how elimination of this restriction would help consumers.").

14. Va. Pharmacy, 425 U.S. at 763.

15. $I d$.

16. Id. at 765 (emphasis added).

17. Id.

18. Id. at 764 . 
artificial furs promotes his product as an alternative to the extinction by his competitors of fur-bearing mammals." ${ }^{19}$ Even though not all advertisements share this characteristic, allowing for the free flow of commercial speech may help to "enlighten public decisionmaking in a democracy."20

All three of these rationales rely heavily upon the informational value of commercial speech to consumers (and, derivatively, to society as a whole). Commercial speech is valued because of its ability to communicate useful information to consumers and to help them make more informed choiceseither about purchasing decisions or topics of more general public interest. These rationales also build off of the "marketplace of ideas" conception of the First Amendment, which posits that "truth is served by a free and full competition of ideas within the community, rather than by paternalistic state-sponsored efforts to protect citizens from the ill effects of bad ideas." 21 The controversial innovation of Virginia Pharmacy was to apply the metaphor of the marketplace of ideas to the actual marketplace, where companies are seeking to sell products, not ideas.

However, unlike the marketplace of ideas in the political realm, which relies on the public's judgment to sort out false or misleading ideas, the Virginia Pharmacy decision made clear that deceptive commercial speech could be regulated and restricted. ${ }^{22}$ In the commercial context, only truthful, nonmisleading speech is constitutionally protected. This is because, under Virginia Pharmacy, commercial speech is entitled to constitutional protection only because it communicates valuable information that can help inform consumers. Justice Stewart wrote a concurrence to emphasize this point: "[T]he elimination of false and deceptive claims serves to promote the one facet of commercial price and product advertising that warrants First Amendment protection[:] its contribution to the flow of accurate and reliable information relevant to public and private

19. Id.

20. Id. at 765. In dissent, then-Justice (later Chief Justice) Rehnquist pointedly argued that extending constitutional protection to all commercial speech because some such speech might inform democratic decisionmaking was dramatically overbroad:

The Court insists that the rule it lays down is consistent even with the view that the First Amendment is "primarily an instrument to enlighten public decisionmaking in a democracy." I had understood this view to relate to public decisionmaking as to political, social, and other public issues, rather than the decision of a particular individual as to whether to purchase one or another kind of shampoo.

ld. at 787 (Rehnquist, J., dissenting) (citation omitted).

21. Ronald J. Krotoszynski, JR., The First Amendment in Cross-Cultural Persfective: A Comparative Legal Analysis of the Freedom of Speech 14 (2006).

22. Va. Pharmacy, 425 U.S. at 771 ("Obviously, much commercial speech is not provably false, or even wholly false, but only deceptive or misleading. We foresee no obstacle to a State's dealing effectively with this problem."). In later cases, the Court has made clear that it draws a distinction between persuasive advertising techniques (such as "impressive endorsements or catchy jingles") and "deceptive or misleading" advertising. See infra note 75 and accompanying text. 
decisionmaking." ${ }^{23}$ Thus, the holding of Virginia Pharmacy can be succinctly summarized as follows: Commercial speech that conveys "accurate and reliable information" is granted constitutional protection, while misleading or manipulative advertising that subverts informed decisionmaking is not. These foundational principles have remained generally consistent features of the Supreme Court's commercial speech doctrine.

\section{B. EARLY COMMERCIAL SPEECH CASES: RESTRICTIONS ON MANIPULATIVE PRACTICES}

The early commercial speech cases reinforced Virginia Pharmacy's concern with the informational value of such speech to consumers. The year after Virginia Pharmacy, the Supreme Court struck down an Arizona Bar regulation prohibiting advertising by attorneys in Bates v. State Bar of Arizona. ${ }^{24}$ Ruling that Arizona could not keep attorneys from advertising their services in newspapers, the Court held that "commercial speech serves to inform the public of the availability, nature, and prices of products and services" and therefore "serves individual and societal interests in assuring informed and reliable decisionmaking." 25 Notably, the Court specifically declined to consider whether more aggressive advertising techniques, such as in-person solicitation, might be considered manipulative and therefore beyond the First Amendment's protection. ${ }^{26}$

Addressing the unanswered question raised in Bates, the Court soon stepped in to uphold restrictions on certain types of advertising deemed misleading or manipulative. In Ohralik v. Ohio State Bar Ass'n, it upheld sanctions on a lawyer who violated state bar rules by engaging in in-person solicitation immediately following a car accident. ${ }^{27}$ The court wrote that in-person solicitations are likely to produce "speedy and perhaps uninformed decisionmaking," rather than the more measured decisionmaking that results from careful consideration and reflection. ${ }^{28}$ Accordingly, post-accident solicitation "actually may disserve the individual and societal interest, identified in Bates, in facilitating 'informed and reliable decisionmaking." "29 Importantly, attorneys were still free to distribute informational advertising to potential clients; it was only the unduly coercive and misleading method of communication that was restricted.

Similarly, in Friedman v. Rogers, the Court upheld a Texas law that prohibited an optometrist from advertising using a trade name (in this case, "Texas

\footnotetext{
23. Va. Pharmacy, 425 U.S. at 781 (Stewart, J., concurring).

24. 433 U.S. 350,382 (1977).

25. Id. at 364 (citing Va. Pharmacy, 425 U.S. at 761-65).

26. $I d$. at 366 .

27. Ohralik v. Ohio State Bar Ass'n, 436 U.S. 447, 449 (1978). In another case decided the same day, the Court distinguished the "purely commercial offers of legal assistance" at issue in Ohralik from litigation used "as a vehicle for . . . political expression." In re Primus, 436 U.S. 412, 422, 431 (1978). The latter category of cases was entitled to broader protection under the First Amendment's free association clause. See id. at 434, 437-38

28. Ohralik, 436 U.S. at 457.

29. Id. at 458 (quoting Bates, 433 U.S. at 364).
} 
State Optical"). ${ }^{30}$ The Court noted that unlike the factual information conveyed in Virginia Pharmacy and Bates, "[a] trade name conveys no information about the price and nature of the services offered" and can instead "be used to mislead the public." "31 For example, an optometrist could "assume a new trade name if negligence or misconduct casts a shadow over the old one." 32 Again the Court emphasized that the commercial speech doctrine was meant to facilitate the distribution of truthful information to consumers. In its first attempts to grapple with the manipulative potential of marketing, the Court suggested that noninformational advertising techniques that misled consumers could be restricted.

\section{CENTRAL HUDSON: A DOCTRINAL FRAMEWORK AT ODDS WITH ITSELF}

In the 1980 Central Hudson case, the Court attempted to create a clearer doctrinal framework out of the case law discussed above. ${ }^{33}$ The Court set forth a four-part test for the review of restrictions on commercial speech (the "Central Hudson test"):

1. To qualify for First Amendment protection, the commercial speech must concern lawful activity and not be misleading. ${ }^{34}$

2. The government's asserted interest in restricting the speech must be substantial. ${ }^{35}$

3. The restriction must directly advance the government's asserted interest. ${ }^{36}$

4. The restriction must not be more extensive than necessary to serve the asserted government interest. ${ }^{37}$

While this framework was intended to clarify the Court's commercial speech doctrine, the flexible and indeterminate nature of the test, as well as the decision's internal inconsistency, confused as much as it clarified. ${ }^{38}$

30. Friedman v. Rogers, 440 U.S. 1, 8, 16 (1979).

31. Id. at 12-13. The Supreme Court later clarified that the government "may not place an absolute prohibition on certain types of potentially misleading information . . . if the information also may be presented in a way that is not deceptive." In re R. M. J., 455 U.S. 191, 203 (1982) (emphasis added). Thus, if presented with the same case today, the Court might well decide it differently, given that trade names can in fact communicate information about a business in a nonmanipulative way. Nonetheless, the general points - that the Court provides less protection to practices deemed manipulative, and that its doctrine focuses on the provision of information-still stand. In re R. $M$. J. repeatedly emphasized that the government "retain[s] the authority to regulate advertising that is inherently misleading or that has proved to be misleading in practice." Id. at 207.

32. Friedman, 440 U.S. at 13 .

33. Cent. Hudson Gas \& Elec. Corp. v. Pub. Serv. Comm'n of N.Y., 447 U.S. 557 (1980).

34. $I d$. at 566 .

35. Id.

36. Id.

37. $I d$.

38. See Robert Post, The Constitutional Status of Commercial Speech, 48 UCLA L. Rev. 1, 5 (2000) ("The fundamental flaw in contemporary commercial speech doctrine, however, is that its primary 
The facts and reasoning of Central Hudson demonstrate the inconsistency at the heart of the Court's commercial speech jurisprudence. On one hand, Central Hudson suggested that the government could legitimately limit the provision of informational commercial speech in order to steer consumer behavior in a particular direction. That was the purpose of the regulation at issue in the case, which barred electric utilities in New York from advertising to promote the use of electricity. The regulation had been adopted in the midst of an energy crisis, with the assumption that limiting advertising for electricity would drive down demand. Nothing in the opinion suggested that this government interest was per se invalid and could not support a regulation that would survive the Court's review. Indeed, the Court readily acknowledged that the government's interest in electricity conservation was substantial (prong two) and that "[t]here is an immediate connection between advertising and demand for electricity" (prong three). ${ }^{39}$

On the other hand, the Court applied the test's fourth prong-whether the regulation was overbroad-in a manner that foreshadowed future trouble for regulations of informational commercial speech. In its analysis of whether the restriction was "more extensive than necessary," the Court posited that requiring the provision of information to consumers about the conservation (or efficient use) of electricity would have been an equally effective-and less speech restrictive-mode of reducing electrical use. ${ }^{40}$ Accordingly, the Court deemed the restriction on promotional advertising to be overbroad and struck it down ${ }^{41}$

The Court's reasoning borrowed heavily from the marketplace-of-ideas conception of the First Amendment suggested in Virginia Pharmacy. The Court concluded that if advertising is producing socially harmful results, the best response is to promote counter-speech and then leave it to consumers to draw their own conclusions..$^{42}$ Indeed, the Court quoted Virginia Pharmacy's statement that "[p]eople will perceive their own best interests if only they are well enough informed, and ... the best means to that end is to open the channels of communication rather than to close them." ${ }^{\text {"43 }}$ This reasoning, however, is in tension - if not at odds - with the overall structure of the Central Hudson test, which assumes that in certain cases the government can limit certain types of commercial speech in order to further important interests (such as public health or public safety). The Central Hudson test thus attempted to incorporate both "a

doctrinal standard, the so-called Central Hudson test, is so vague and abstract as to fail entirely to express any specific constitutional values." (footnote omitted)); $c f .44$ Liquormart, Inc. v. Rhode Island, 517 U.S. 484, 528 (1996) (Thomas, J., concurring in part and concurring in the judgment) (criticizing the Central Hudson test for asking courts to simultaneously "apply contradictory premises-that informed adults are the best judges of their own interests, and that they are not").

39. Cent. Hudson, 447 U.S. at 569.

40. Id. at $569-71$.

41. Id. at 571 .

42. Id. at $561-62$.

43. Id. at 562 (quoting Va. State Bd. of Pharmacy v. Va. Citizens Consumer Council, 425 U.S. 748 , $770(1976))$ 
pragmatic inclination to defer to reasonable legislative judgments" and "an anti-paternalistic impulse that condemns governments for acting on fears that truthful information will encourage people to make bad choices," while providing legislatures and the courts virtually no guidance on how these two contradictory impulses were to be reconciled. ${ }^{44}$

The Court's method of analysis, however, suggested that most restrictions on commercial speech would have difficulty surviving the Central Hudson test's fourth prong. The factual conclusion underlying the Court's decision on this prong-that a government-mandated disclaimer would have been an equally effective means of reducing electricity consumption-makes sense only if one assumes that advertising is essentially informational, and that consumers will give equal weight to other, competing information (in this case, the hypothetical disclaimers). Such a conclusion seems hopelessly divorced from the reality of modern advertising, which is focused on "shap [ing] consumer preferences and creat[ing] irrational associations for products," rather than the bare provision of information. ${ }^{45}$ Decades of behavioral research suggest that persuasive advertising is likely to have a more powerful impact on consumers than the provision of government-mandated informational disclosures. ${ }^{46}$ Nonetheless, if one assumes, as the Court did, that "more speech" is always the appropriate response to problematic speech, it is hard to see how any restrictions on advertising could be justified by the Central Hudson test. ${ }^{47}$ Counter-speech, either directly by the government or through mandated disclosures, would always be a less restrictive alternative. $^{48}$

In the years following Central Hudson, the test has begun to look more like strict scrutiny because of this inherent tension. The Court has readily accepted

44. Allen Rostron, Pragmatism, Paternalism, and the Constitutional Protection of Commercial Speech, 37 VT. L. REv. 527, 531 (2013).

45. Wendy E. Parmet \& Jason A. Smith, Free Speech and Public Health: A Population-Based Approach to the First Amendment, 39 Loy. L.A. L. REv. 363, 416 (2006) (noting that "advertising does far more than provide rational consumers with useful information about legitimate products").

46. See, e.g., Linda J. Demaine, Seeing Is Deceiving: The Tacit Deregulation of Deceptive Advertising, 54 ARIz. L. REv. 719, 751-52 (2012) (discussing the "superior persuasive power of visual imagery over verbal assertions," and noting that "advertisers convey deceptive messages in visual imagery while relegating the offsetting disclosures to verbiage"); Rebecca Tushnet, Trademark Law as Commercial Speech Regulation, 58 S.C. L. Rev. 737, 742-43 (2007) ("Even disclaimers that are, on their face, clear and unambiguous rarely affect consumer perceptions in the overall context of advertising or packaging."). To be fair, much of this research postdates the Central Hudson decision in 1980. Nonetheless, even in 1980, it was clear that a considerable amount of advertising-both on television and in print-was not primarily informational. See infra text accompanying note 81 .

47. Cent. Hudson, 447 U.S. at 577 (Blackmun, J., concurring in the judgment) (quoting Linmark Assocs., Inc. v. Twp. of Willingboro, 431 U.S. 85, 97 (1977)).

48. Note that the counterspeech would have to come from the government - at some significant cost to taxpayers. In the free market, even if there are a variety of sellers (unlike the monopolistic case at issue in Central Hudson), all of the sellers will always be promoting more consumption. If the government's goal is to reduce consumption - either of energy or of harmful products-it cannot rely on the marketplace to deliver that message. This is one example of how the marketplace-of-ideas metaphor is inapplicable to the actual marketplace. 
the asserted government interests - reducing alcohol use, for example ${ }^{49}$-as a substantial interest for purposes of the test's second prong. But relying on the marketplace-of-ideas paradigm, it has moved toward the position that keeping information (as the Court has characterized advertising) from adult consumers in order to influence their behavior is inappropriately paternalistic, and therefore any restriction justified on that basis fails the test's fourth prong. This doctrinal approach essentially drains the Central Hudson test of any value, at least as applied to restrictions on "informational" commercial speech. If no restrictions on truthful, nonmanipulative speech can survive Central Hudson review-then although the test may provide for intermediate scrutiny in theory-it is inevitably fatal in fact.

\section{FROM CENTRAL HUDSON TO SORRELL: TOWARD STRICTER REVIEW}

The cases following Central Hudson have gradually moved in the direction of stricter and stricter review of limits on commercial speech, but this evolution was gradual and did not begin immediately. Six years after the Central Hudson decision, in Posadas de Puerto Rico Associates v. Tourism Co. of Puerto Rico, the Court moved in the other direction, suggesting that restrictions on informational advertising might easily pass muster under the Central Hudson test if supported by a sufficiently important government interest. ${ }^{50}$ Although this case is no longer good law, it is worth reviewing in order to better understand the conceptual approach underlying the Court's application of the Central Hudson test.

In Posadas, the Court upheld a ban on casino advertising. As in Central Hudson, the governmental interest was characterized as a reduction in consumption - in this case, of casino gambling. ${ }^{51}$ Applying the fourth prong of the Central Hudson test, then-Justice Rehnquist's majority decision dismissed the argument that counter-speech discouraging gambling was a less restrictive means that the government should have been compelled to pursue. He wrote:

We think it is up to the legislature to decide whether or not such a "counterspeech" policy would be as effective in reducing the demand for casino gambling as a restriction on advertising. The legislature could conclude, as it apparently did here, that residents of Puerto Rico are already aware of the risks of casino gambling, yet would nevertheless be induced by widespread advertising to engage in such potentially harmful conduct. ${ }^{52}$

49. See, e.g., Rubin v. Coors Brewing Co., 514 U.S. 476, 485 (1995) (recognizing that "the Government ... has a significant interest in protecting the health, safety, and welfare of its citizens").

50. See generally 478 U.S. 328 (1986). Technically, the restriction applied only to advertising to the public of Puerto Rico; advertising outside of Puerto Rico was not restricted. The ban on only local advertising was justified as an attempt to promote economically valuable tourism while protecting the local population from the negative effects of gambling.

51. Id. at $340-41$

52. Id. at 344 . 
In other words, then-Justice Rehnquist-who was the only dissenter in both Virginia Pharmacy and Central Hudson-rejected the contention that all speech should be weighted equally. The majority applied a susceptible-consumer construct, rather than a rational-consumer model, in acknowledging the persuasive power of advertising. ${ }^{53}$ Advertising, the Court suggested, can encourage consumers to engage in behavior that they know is harmful, and the state has a valid interest in restricting such advertising.

This turn toward a more lenient approach to commercial speech regulations was short lived. The strength of Posadas as a precedent was gradually eroded over the next decade, and it was expressly overruled in 1996 in 44 Liquormart, Inc. v. Rhode Island. ${ }^{54}$ In a unanimous decision, but with fractured reasoning, the Court struck down a Rhode Island law prohibiting price-related advertising for alcoholic beverages. ${ }^{55}$ The plurality opinion, written by Justice Stevens, emphatically rejected the view expressed in Posadas that the government could restrict informational advertising in order to influence consumer decisionmaking. He wrote:

Precisely because bans against truthful, nonmisleading commercial speech rarely seek to protect consumers from either deception or overreaching, they usually rest solely on the offensive assumption that the public will respond "irrationally" to the truth. The First Amendment directs us to be especially skeptical of regulations that seek to keep people in the dark for what the government perceives to be their own good. That teaching applies equally to state attempts to deprive consumers of accurate information about their chosen products ... 56

53. See Sarah C. Haan, The "Persuasion Route" of the Law: Advertising and Legal Persuasion, 100 Colum. L. Rev. 1281, 1284-85 (2000) (discussing how the Supreme Court's commercial speech cases reflect the "rational-consumer theory that was popularized by the Chicago School of Economics in the 1960 s and 1970s").

54. 517 U.S. $484,509-10$ (1996).

55. Justice Stevens, joined by three other justices, wrote that "more stringent constitutional review" was required when "a blanket prohibition against truthful, nonmisleading speech about a lawful product" was at issue. Id. at 504, 508. Justice Thomas would have gone further and jettisoned the Central Hudson test entirely. He argued that restrictions on truthful, informational commercial speech are per se illegitimate when the government's interest is to "keep legal users of a product or service ignorant in order to manipulate their choices in the marketplace." Id. at 518 (Thomas, J., concurring in part and concurring in the judgment). By contrast, Justice O'Connor, joined by three Justices (oddly including Justice Souter, who also joined the section of Justice Stevens's opinion quoted above), wrote that the law in question clearly failed the existing Central Hudson test, and there was therefore no need to break new doctrinal ground. $I d$. at 532 (O'Connor, J., concurring in the judgment).

56. Id. at 503 (plurality opinion) (citation omitted); see also id. at 510 ("[I]n keeping with our ... holdings [other than Posadas], we conclude that a state legislature does not have the broad discretion to suppress truthful, nonmisleading information for paternalistic purposes that the Posadas majority was willing to tolerate. As we explained in [Virginia Pharmacy], "[i]t is precisely this kind of choice, between the dangers of suppressing information, and the dangers of its misuse if it is freely available, that the First Amendment makes for us."' (alteration in original) (quoting Va. Bd. of Pharmacy v. Va. Citizens Consumer Council, Inc., 425 U.S. 748, 770 (1976))). 
Justice Stevens thus argued that the state's concern about consumers being unduly persuaded by informational advertising was an invalid (or at least highly disfavored) basis for government regulation. At the same time, however, he added that where the state regulated commercial speech in order to protect consumers "from either deception or overreaching," and thereby preserve "a fair bargaining process," more deferential review remained appropriate. ${ }^{57}$ In Justice Stevens's view, which came to command majority support on the Court, the state carries an exceedingly heavy burden in seeking to limit informational advertising, but advertising that is "misleading, deceptive, or aggressive" can be more easily regulated, consistent with the purposes of the commercial speech doctrine..$^{58}$

The cases following 44 Liquormart have followed this general framework. The bar for regulating commercial speech in order to influence consumer decisionmaking has been gradually ratcheted up over time, with Justice Stevens's concern about governmental paternalism playing a more and more prominent role. In Thompson v. Western States Medical Center, for example, the Court rejected an FDA rule restricting the advertising of compounded pharmaceuticals. ${ }^{59}$ The FDA argued that overuse of compounded pharmaceuticals presented public health risks, ${ }^{60}$ but the Court again "rejected the notion that the Government has an interest in preventing the dissemination of truthful commercial information in order to prevent members of the public from making bad decisions with the information." ${ }^{61}$ The Court reemphasized that restrictions on truthful, nonmisleading commercial speech must be the "last—not first—resort."62

The Court's most recent commercial speech case, Sorrell v. IMS Health, Inc., arguably went somewhat further. At issue was a Vermont law that limited the

57. Id. at 501, 503; see also id. at 501 (writing that "[w]hen a State regulates commercial messages to protect consumers from misleading, deceptive, or aggressive sales practices," the Court should apply "less than strict review").

58. Id.; see also Post, supra note 38, at 47 (explaining that Justice Stevens's opinion in 44 Liquormart suggests an extremely high level of protection for commercial speech, "unless the government can adduce interests specifically applicable to commercial speech, like "the preservation of a fair bargaining process,' which justify diminishing these protections").

59. 535 U.S. $357,376(2002)$.

60. Concern for these health risks was borne out in 2012, when a large-scale compounding center in Massachusetts caused an outbreak of fungal meningitis. See generally Kevin Outterson, Regulating Compounding Pharmacies After NECC, 367 NEw ENG. J. MED. 1969 (2012).

61. Thompson, 535 U.S. at 374. Interestingly, Justice Stevens joined the dissent, perhaps persuaded by Justice Breyer's argument that the government's motivation in this case was not a paternalistic one. See id. at 387 (Breyer, J., dissenting) ("It is an oversimplification to say that the Government 'fear[s]' that doctors or patients 'would make bad decisions if given truthful information.' Rather, the Government fears the safety consequences of multiple compound-drug prescription decisions initiated not by doctors but by pharmacist-to-patient advertising. Those consequences flow from the adverse cumulative effects of multiple individual decisions each of which may seem perfectly reasonable considered on its own. The Government fears that, taken together, these apparently rational individual decisions will undermine the safety testing system, thereby producing overall a net balance of harm." (alteration in original) (citations omitted)).

62. Id. at 373 (majority opinion) 
sale and use of pharmacy records that identified the prescribing physician. ${ }^{63}$ Under the law, pharmaceutical marketers were barred from using this factual information for commercial purposes. ${ }^{64}$ Justice Kennedy's opinion for the Court announced that restrictions on commercial speech-and, in particular, those based on the government's attempt to influence behavior-required an unspecified level of "heightened judicial scrutiny." 65 As he explained, "Those who seek to censor or burden free expression often assert that disfavored speech has adverse effects. But the 'fear that people would make bad decisions if given truthful information' cannot justify content-based burdens on speech."66

Although the decision did not formally overturn Central Hudson, this language arguably suggests that no restrictions on commercial speech will survive the Supreme Court's review if the purpose of the restriction is to restrict truthful, nonmisleading advertising for a legal product. ${ }^{67}$ Importantly, six Justices, including Justice Sotomayor, signed the majority opinion in Sorrell, signaling that a stable majority of the Court is highly skeptical of restrictions on commercial speech that it views as paternalistic. ${ }^{68}$

While suggesting a heightened level of scrutiny, Sorrell remained focused on the informational value of commercial speech as the key justification for its constitutional protection. For example, in discussing the restriction at issue, which limited the sale and use of prescriber-identifying pharmacy information, the Court harkened back to Virginia Pharmacy: "A 'consumer's concern for the free flow of commercial speech often may be far keener than his concern for urgent political dialogue.' That reality has great relevance in the fields of

63. Sorrell v. IMS Health Inc., 131 S. Ct. 2653, 2659 (2011) (striking down a Vermont law limiting the sale and use of individual pharmacy records that identified the prescribing physician).

64. This ban on the use of prescriber-identifiable information was subject to certain exceptions, such as provider consent. $I d$. at 2660.

65. Id. at 2659. But see id. at 2667 (suggesting that the Central Hudson test did not need to be reconsidered because "the outcome is the same whether a special commercial speech inquiry or a stricter form of judicial scrutiny is applied"). Clearly signaling the application of a heightened standard of review, the Court cited and applied numerous precedents that involved noncommercial political or ideological speech in its analysis of the law at issue in Sorrell.

66. Id. at 2670-71 (quoting Thompson, 535 U.S. at 374).

67. See Tamara R. Piety, "A Necessary Cost of Freedom"? The Incoherence of Sorrell v. IMS, 64 Ala. L. Rev. 1, 4 (2012) (suggesting that Sorrell "essentially render[ed] the Central Hudson test irrelevant" and that "henceforth, in practice, if not formally, commercial speech will be treated as fully protected"). I do not mean to suggest that this is the only possible reading of Sorrell, only that it is a plausible one based on the text of the opinion. Cf. Jennifer L. Pomeranz, No Need to Break New Ground: A Response to the Supreme Court's Threat to Overhaul the Commercial Speech Doctrine, 45 Loy. L.A. L. REv. 389 (2012) (arguing that Sorrell does not necessarily signify a dramatic break from prior case law and that the Court should continue to apply the Central Hudson test in commercial speech cases).

68. Troublingly, Sorrell also broke new ground by citing as precedent numerous cases that came from outside of the commercial speech context, thereby muddling the distinction between the regulation of commercial and noncommercial speech. See, e.g., Sorrell, $131 \mathrm{~S}$. Ct. at 2663-65 (citing R.A.V. v. City of St. Paul, 505 U.S. 377 (1992)) (incorporating the concept of "viewpoint discrimination" from the noncommercial context). 
medicine and public health, where information can save lives." ${ }^{69}$ Similarly, the Court emphasized that many doctors (the most relevant consumers in this case), found the pharmaceutical detailing based on the restricted information to be "instructive" and "very helpful." "70 Because of the informational value to consumers of the speech at issue, the Court suggested, as in previous cases, that the government's response should be to "express [its] view through its own speech," rather than to restrict the free flow of information. ${ }^{71}$

While providing strong protection for "truthful, nonmisleading advertisements," the Court suggested in Sorrell that a lower standard should apply if the government were restricting commercial speech for a "neutral" purpose aimed at "protecting consumers from "commercial harms.",72 Though the Court specifically mentioned the potential for fraud as one such example, that same reasoning would presumably apply to other regulations intended to protect the fairness of commercial exchanges. ${ }^{73}$

The Supreme Court's commercial speech cases show a heightened level of scrutiny being applied over time. This analysis demonstrates, however, that the higher standard of review is being applied only in cases where the governmental purpose is to withhold information from consumers. Though obfuscated by the fact that the Court has struck down commercial speech restrictions in case after case, the Court has consistently stated that restrictions on commercial speech intended to preserve the fairness of the bargaining process do not merit the same level of scrutiny. In Central Hudson, for example, the Court stated that "[t]he government may ban forms of communication more likely to deceive the public than to inform it." ${ }^{\text {"74 }}$ Although Sorrell makes clear that the Court does not equate

69. Id. at 2664 (emphasis added) (citation omitted) (quoting Bates v. State Bar of Ariz., 433 U.S. 350,364 (1977)).

70. Id. at 2671 (internal quotation marks omitted).

71. $I d$.

72. Id. at 2671-72 ("[T]he government's legitimate interest in protecting consumers from "commercial harms' explains 'why commercial speech can be subject to greater governmental regulation than noncommercial speech."” (quoting City of Cincinnati v. Discovery Network, Inc., 507 U.S. 410, 426 (1993))).

73. Id. at 2672.

74. Cent. Hudson Gas \& Elec. Corp. v. Pub. Serv. Comm'n of N.Y., 447 U.S. 557, 563 (1980). There has been limited case law applying this prong of the Central Hudson test. In a few cases, the Supreme Court has struck down restrictions on types of commercial speech that were alleged to be manipulative. In all of these cases, however, the Court was convinced that the speech at issue was not actually manipulative. To the contrary, it felt that the restricted speech provided information that was valuable to consumers. See, e.g., Ibanez v. Fla. Dep't of Bus. \& Prof'l Regulation, 512 U.S. 136 (1994) (invalidating rule prohibiting an attorney from referring to his or her certification as a Certified Public Accountant or Certified Financial Planner); Peel v. Att'y Registration \& Disciplinary Comm'n of Ill., 496 U.S. 91 (1990) (striking bar rule prohibiting attorney from advertising certification as a trial specialist); Zauderer v. Office of Disciplinary Counsel of the Supreme Court of Ohio, 471 U.S. 626 (1985) (finding that attorney had First Amendment right to use factual illustration of Dalkon Shield intrauterine device in ad to solicit representation of those who had used the device) 
overly persuasive advertising with deceptive advertising, ${ }^{75}$ there is still considerable room to argue that speech that undermines the fairness of the commercial exchange_even if not technically false or factually misleading-is antithetical to the purposes of the commercial speech doctrine. ${ }^{76}$ That was the central holding of the Ohralik decision, which has been consistently followed by lower courts. ${ }^{77}$

The Supreme Court's commercial speech cases arguably support a broader point: noninformational commercial advertising does not further the purposes of the commercial speech doctrine and merits limited, if any, First Amendment protection. After all, the Court in Virginia Pharmacy defined advertising as the communication of information, writing that "[a]dvertising, however tasteless and excessive it sometimes may seem, $i$ s nonetheless dissemination of information as to who is producing and selling what product, for what reason, and at what price."78 Noninformational advertising-for example, the use of cartoon characters to promote children's cereals-is pure persuasion that in no way helps consumers to make better informed choices. ${ }^{79}$ Some have therefore pushed for a doctrinal distinction between the informational and noninformational elements of advertising, with the informational elements-verifiable information about a product's characteristics, price, availability, etc.—strongly

75. Sorrell, $131 \mathrm{~S}$. Ct. at 2671 ("[T]he State may not seek to remove a popular but disfavored product from the marketplace by prohibiting truthful, nonmisleading advertisements that contain impressive endorsements or catchy jingles."). Note the qualification that the advertisement must be nonmisleading in order to qualify for protection.

76. In the context of compelled speech cases, the Supreme Court has repeatedly reinforced this point, upholding compelled disclosures when deemed necessary to protect the fairness of the bargaining process, but applying heightened scrutiny when used for other purposes. See, e.g., Zauderer, 471 U.S. at 651 (upholding requirement for a "factual and uncontroversial" disclosure about the cost of legal services and writing that "an advertiser's rights are adequately protected as long as disclosure requirements are reasonably related to the State's interest in preventing deception of consumers"); Milavetz, Gallop \& Milavetz, P.A. v. United States, 559 U.S. 229, 252-53 (2010) (upholding disclosure requirements for "debt relief agenc[ies]" because they were "reasonably related to the [Government's] interest in preventing deception of consumers" (quoting Zauderer, 471 U.S. at 651) (alteration in original)); Pac. Gas \& Elec. Co. v. Pub. Utilities Comm'n of Cal., 475 U.S. 1, 20-21 (1986) (applying heightened scrutiny and striking down requirement for utility to provide space to opposing views in its newsletter). But see Am. Meat Inst. v. U.S. Dep't of Agric., 760 F.3d 18, 22-23 (D.C. Cir. 2014) (en banc) (holding that the less rigorous Zauderer standard is not limited "to cases in which the government points to an interest in correcting deception," but instead applies more broadly to other circumstances in which the government's interest in requiring a warning or disclaimer is substantial).

77. See, e.g., Walraven v. N.C. Bd. of Chiropractic Examiners, 273 F. App'x 220, 222-23 (4th Cir. 2008) (upholding limits on solicitation by chiropractors within ninety days following an accident); Nat'l Funeral Servs., Inc. v. Rockefeller, 870 F.2d 136, 138 (4th Cir. 1989) (applying Central Hudson and upholding ban on solicitation for pre-need funeral contracts in nursing homes and hospitals); Bergman v. District of Columbia, 986 A.2d 1208, 1211 (D.C. 2010) (sustaining limits on post-accident solicitation by attorneys).

78. Va. State Bd. of Pharmacy v. Va. Citizens Consumer Council, Inc., 425 U.S. 748, 765 (1976) (emphasis added).

79. The cartoon character may be part of an advertisement that does contain information, but the character, on its own, is not informative in any way. Even if the associated informational content is protected by the commercial speech doctrine, one could argue that the noninformational advertising elements (the cartoon characters, in this example) should be more easily subject to regulation. 
protected, but the noninformational components more easily subject to restriction. ${ }^{80}$ Somewhat surprisingly, the issue of noninformational advertising has never been squarely presented to the Supreme Court. The Court's cases have either addressed restrictions on clearly informational advertising, or the Court has assumed the advertising at issue to be informational, without any serious discussion of the issue.

Dating back to Virginia Pharmacy, the Court's commercial speech cases have consistently stated that truthful, informational commercial speech is protected, while false and misleading speech can be restricted. But a considerable amount of doctrinal space between these two poles has been left unexplored. For example: To what extent is noninformational commercial speech protected? What does misleading mean in an era of noninformational advertising? The remainder of this Article seeks to examine some of that uncharted doctrinal space by examining noninformational commercial speech that manipulates consumer decisionmaking. Such speech does not further any of the commercial speech doctrine's purposes; to the contrary, it undermines and inhibits the rational and autonomous processing of commercial information that the doctrine was intended to promote.

\section{Manipulative Marketing}

Before defining and providing examples of "manipulative marketing," this Part takes two necessary detours. First, it explores the wide gap between the Supreme Court's information-focused conception of advertising and the reality that most advertising employs noninformational methods of persuasion. Second, it examines the insights of behavioral psychology and neuroscience, which explain why companies are increasingly employing sophisticated "neuromarketing" techniques in an effort to influence consumers at a subconscious level. Manipulative marketing is the product of the convergence of these two trends, the decline of "informational" marketing and the rise of advertising that takes advantage of consumers' cognitive limitations. (It is quite distinct from false or factually misleading advertising, which is adequately addressed under current doctrine.) After defining the term and providing some detailed examples of manipulative marketing, this section concludes by explaining why one possible regulatory intervention - mandated disclosures - is an ineffective and inappropriate response to the problem.

\section{A. MODERN MARKETING AND THE COLLAPSE OF THE INFORMATIONAL PARADIGM}

From Virginia Pharmacy through Sorrell, the Supreme Court has centered its commercial speech doctrine on the informational value of commercial advertising. This focus on the informational content of advertising, however, was probably outdated even when the Supreme Court decided Virginia Pharmacy in

80. Hammer, supra note 9 , at 470. 
1976, and is certainly anachronistic now. Since at least the 1970s, "there has been a noticeable decrease in the quantity of information contained in advertisements and a move towards advertisements focusing on visual images designed to produce emotional responses in viewers." ${ }^{81}$ As summarized by Sarah Haan:

In the 1970s, around the time rational consumer theory was producing favorable legal outcomes for advertisers, researchers conducted a string of studies on information content in advertising. Most concluded that the great majority of ads contain little factual information about the products they tout. The three earliest of these studies, published in 1977, found that television and print advertisements contained minimal information content ....

Recent studies continue to confirm the finding that ads do not contain much information.

$\ldots$

... Television commercials have become shorter, words in print ads have become fewer, and appeals to image and emotion have substituted for appeals emphasizing product claims. ${ }^{82}$

In short, the trend since the 1970 s has been for advertising to rely more and more heavily on lifestyle associations and emotional appeals, rather than the conveyance of information about the product. The tobacco industry helped to pioneer this approach, famously using the Marlboro Man to "creat[e] demand for Marlboros and other cigarettes by conveying to smokers a sense of independence, autonomy, and sexuality" - characteristics that are by no means inherent in the products themselves. ${ }^{83}$ This approach was wildly successful; Marlboro's sales increased by $300 \%$ in the first two years of the Marlboro Man campaign (despite mounting revelations about the dangers of cigarettes). ${ }^{84}$ The success of the tobacco industry's marketing pushed other industries toward similar advertising techniques. Any casual glance at television or print advertisements today

81. Id. at 442. Hammer provides the example of a study of full-page advertisements in Time magazine. The study showed:

[A]dvertisements published in January 2000 contained, on average, half the amount of words contained in advertisements published in the magazine's January 1976 editions. This trend was even more pronounced if one discounted cigarette advertisements (the magazine did not advertise cigarettes in 2000), in which case there was a drop from 282 to 100 words.

Id. at 442-43 (footnote omitted).

82. Haan, supra note 53, at 1292-93, 1296; id. at 1293 (noting, for example, that "a 1989 study of prime-time commercials broadcast from 1976 to 1986 reported that consumers found a mere two percent 'very informative,' and about a third 'slightly informative"').

83. Jon D. Hanson \& Douglas A. Kysar, Taking Behavioralism Seriously: Some Evidence of Market Manipulation, 112 Harv. L. Rev. 1420, 1471 (1999).

84. Katie Connolly, Six Ads That Changed the Way You Think, BBC News (Jan. 3, 2011, 4:44 PM), http:/www.bbc.co.uk/news/world-us-canada-11963364. The Marlboro Man campaign was launched in 1955. Id. Another incredibly successful example of lifestyle advertising was (and remains) Nike's shoe advertising. These ads, including Nike's famous "Just Do It" campaign, typically include no information whatsoever about Nike's shoes. As one advertising expert put it, "Nike's great insight was [to] forget the shoe, own the athlete." Id. 
will show that a significant percentage of ads focus on conveying "a particular image-young, hip, virile, affluent, and so forth"-rather than information about the product. ${ }^{85}$

The reason for this transition toward advertising with little or no informational content is obvious: it works. Decades of marketing research have confirmed "that emotional and experiential advertisements, rather than informational ones, are much more successful in causing viewers to internalize the advertising messages." ${ }^{86}$ Business students are now instructed that "consumers do not base their decisions on knowledge" 87 and-perhaps more surprisingly-that the provision of information "may actually hinder persuasion" and make advertising less effective. ${ }^{88}$ This advice is backed up by studies suggesting that ease of mental processing is key to persuasion. In experimental settings, "the more information subjects were required to process to compare a brand with others, the less likely they were to choose that brand." 89

The sharp reduction in the informational content of advertising certainly calls into question the soundness of a commercial speech doctrine built around an informational advertising paradigm. Even accepting the Court's doctrinal approach, however, the increasing reliance on noninformational, emotional advertising suggests the possibility that some subset of current advertising is manipulative in legally relevant ways. At issue is not simply the lack of information in advertising, but what advertisers are replacing that information with: content that is intended (with ever-increasing scientific precision) to evade or subvert rational decisionmaking and instead influence consumer decisionmaking — often without the consumers even aware that they are being influenced.

\section{B. TARGETING THE SUBCONSCIOUS: NEUROMARKETING AND THE DUAL-PROCESSING}

\section{MODEL OF DECISIONMAKING}

Businesses spend approximately $\$ 21$ billion a year in the United States alone on marketing research. ${ }^{90}$ Among other techniques:

They hire researchers and marketing specialists to conduct "day after" phone surveys to gauge the effectiveness of advertisements, organize focus groups in shopping malls, and encourage fantasy role-playing among consumers of household products. They track customer search patterns within stores using

85. Horwitz, supra note 2, at 56.

86. Hammer, supra note 9, at 437; see also Les Binet \& Peter Field, Empirical Generalizations About Advertising Campaign Success, 49 J. AdVERTISIng Res. 130, 131 (2009) ("The more emotions dominate over rational messaging, the bigger the business effects. The most effective advertisements of all are those with little or no rational content.").

87. Hammer, supra note 9 , at 440 .

88. Haan, supra note 53 , at 1297.

89. Id. at 1298.

90. Stephen Morea, IBISworld, IBISWorld Industry Report 54191: Market Research in the US 4 (2014), available at http://ibisworld.com/industry/default.aspx ?indid=1442. 
hidden cameras [and] monitor eye responses to magazine ad layouts with ultrasensitive equipment . . . . ${ }^{91}$

Increasingly, manufacturers are also turning to "neuromarketing" specialists, who use advanced brain monitoring technologies such as functional magnetic resonance imaging (fMRI) and portable electroencephalography (EEG) to measure the brain's response to marketing stimuli in real time. ${ }^{92}$ Neuromarketing research is a particularly powerful tool because it "allows companies to determine individuals' emotional responses to brands and brand preferences, even when the individual may be unaware of the brand's effect on his or her subconscious decision making."93

Marketing, neuromarketing, and social psychological research have all converged on "dual-processing models" of human thought and behavior, which posit that "behavior is produced by both intentional, conscious, 'explicit' thought and unintentional, nonconscious, 'implicit' thought." 94 The implicit, nonconscious mode of decisionmaking is sometimes referred to as System 1, while the explicit, intentional mode is referred to as System 2. ${ }^{95}$ Research continues to demonstrate that much of human decisionmaking (much more than previously thought) is nonconscious and intuitive. ${ }^{96} \mathrm{~A}$ relatively small percentage, by contrast, "involve[s] what we usually associate with the word thinking."97

91. Hanson \& Kysar, supra note 83, at 1429.

92. See Douglas L. Fugate, Neuromarketing: A Layman's Look at Neuroscience and Its Potential Application to Marketing Practice, 24 J. Consumer Marketing 385, 385-86 (2007).

93. Marisa E. Main, Simply Irresistible: Neuromarketing and the Commercial Speech Doctrine, 50 DuQ. L. REv. 605, 621 (2012). For an example of a neuromarketing firm, see NEURo-Insight, http://www. neuro-insight.com (last visited Jan. 16, 2015). The CEO of Neuro-Insight, Pranav Yadav, was recently named to Forbes magazine's "30 Under 30" list. Neuro-Insight CEO Pranav Yadav on the Annual Forbes ' 30 Under 30' List, NeURogadGeT (Jan. 9, 2014), http://neurogadget.com/ 2014/01/09/neuroinsight-ceo-pranav-yadav-annual-forbes-list-30-30/9279. The company uses patented technology "to track second by second changes in brain activity, allowing them to deliver insights into how a piece of design or advertising is affecting people at both a rational and an emotional level." Id.; see also Nicholas Freudenberg, Lethal but Legal: Corporations, Consumption, and Protecting Public Health 13 (2014) (discussing neuromarketing firm NeuroFocus, which has developed "the world's first portable, wireless electroencephalogram (EEG) scanner" and uses it to "chart[] consumer reactions to the commercials, products, and brands of its clients").

94. See David J. Arkush, Situating Emotion: A Critical Realist View of Emotion and Nonconscious Cognitive Processes for Law and Legal Theory, 2008 BYU L. REv. 1275, 1297; see also RiCHARD H. Thaler \& Cass R. Sunstein, Nudge: Improving Decisions about Health, Wealth, and Happiness 19-21 (2008) (referring to the two systems as the "Reflective System" and the "Automatic System," and explaining that "[o]ne way to think about all this is that the Automatic System is your gut reaction and the Reflective System is your conscious thought").

95. Daniel Kahneman, Thinking, Fast and Slow 20-21 (2011).

96. See Arkush, supra note 94, at 1298 ("Although researchers originally thought nonconscious cognition was limited to simple mental processes, they now believe that it dominates our lives. Nonconscious behavioral processes are so ubiquitous, robust, and effective that some are left wondering what purpose conscious reasoning serves."); see also Gerald Zaltman, How Customers Think: Essential Insights into the Mind of THE MARKet 40 (2003) ("According to most estimates, about 95 percent of thought, emotion and learning occur in the unconscious mind-that is, without our awareness.").

97. See Thaler \& Sunstein, supra note 94, at 19. 
This is not to suggest that the explicit, reasoning mode of decisionmaking does not play a crucial role, particularly in important decisionmaking tasks that demand focused attention. But the explicit mode of processing requires concentration and energy. Those whose mental energies are focused on other types of decisionmaking - relating to work obligations, family responsibilities, etc.-are likely to rely on their implicit decisionmaking for noncritical, more routine decisions. In effect, decisionmaking is put on "autopilot" when cognitive resources are otherwise engaged or exhausted. This is why people who are tired or distracted can drive home from work without remembering the drive at all. ${ }^{98}$ For the same reason, those whose cognitive facilities are otherwise "used up" are "more likely to be swayed by nonrational cues."

Moreover, to an extent people do not usually recognize, the explicit mode of decisionmaking is deeply intertwined with the implicit mode. ${ }^{100}$ Even when we believe we are thinking dispassionately and rationally, the process is powerfully modulated by "memories, emotions, thoughts, and other cognitive processes we're not aware of or that we can't articulate."101 As Daniel Kahneman summarizes:

System 1 runs automatically and System 2 is normally in a comfortable low-effort mode, in which only a fraction of its capacity is engaged. System 1 continuously generates suggestions for System 2: impressions, intuitions, intentions, and feelings. If endorsed by System 2, impressions and intuitions turn into beliefs, and impulses turn into voluntary actions. When all goes smoothly, which is most of the time, System 2 adopts the suggestions of System 1 with little or no modification. You generally believe your impressions and act on your desires, and that is fine- usually. ${ }^{102}$

Usually this division of mental effort is efficient. But not when marketers try to exploit this dual-processing mode of decisionmaking.

\section{Application of the Dual-Processing Model to Marketing}

The dual-processing mode of decisionmaking has numerous practical applications for advertisers, only a few of which will be reviewed here. For one, advertisers now believe that the more the explicit processing system (System 2) is engaged, the less persuasive an advertisement is likely to be. Therefore, it is

98. See Kent Greenfield, The Myth of Choice 50-51 (2011).

99. Haan, supra note 53 , at 1305.

100. See Kahneman, supra note 95, at 21 (noting that "[a]lthough System 2 believes itself to be where the action is," it is actually System 1 that is "originating impressions and feelings that are the main sources of the explicit beliefs and deliberate choices of System 2").

101. See ZaLtMan, supra note 96, at 9. Zaltman provides an example: "[A] perfume's fragrance-a product attribute - may evoke a particular memory and an associated emotion in a potential buyer. If the memory triggers a painful emotion, then the individual probably won't buy the perfume, even if the fragrance, price, packaging, brand label, and other qualities meet her criteria." Id. at 8 .

102. KAHNEMAN, supra note 95 , at 24. 
to an advertiser's benefit not to provide the type of information that would engage the parts of the brain that focus on rational decisionmaking. ${ }^{103}$ This accounts for the rise in advertisements that rely on noninformational, emotional cues-communication directed at the implicit processing system (System 1). As Gerald Zaltman, an early neuromarketing researcher, explains, "[i]f our old brain parts [the implicit processing system] decide a product will make us feel connected to a larger group or help us hook up with a desirable mate, we're going to want to buy it." 104

Neuromarketing technologies now allow marketing researchers to see exactly when the prefrontal cortex-which governs logic and reasoning-is engaged, and when it is not. Likewise, they can monitor when decisionmaking is being governed by the limbic system-the "old brain" that governs nonconscious, emotional thought. Appeals to emotion (and short-term rewards) can make it more likely that the limbic system dominates decisionmaking, which often works to marketers' advantage. With advances in technology, "neuroscience can now be used to test emotional appeals and determine which emotional appeal generates the ideal levels of limbic system activity." ${ }^{105}$ Indeed, by using neuroimaging technology to view whether (and to what extent) various parts of the brain are engaged, researchers can now "predict whether we will make a purchase before we [consciously] make the decision." 106

Another key application of the dual-processing model is the understanding that mood states, or "affect," are critical to decisionmaking. Those in a positive mood "are more likely to rely on heuristic [nonconscious] cues and to pay less attention to details, whereas individuals who are in negative affective states are more likely to engage in systematic and detail-oriented processing." 107 Accordingly, advertisers believe that putting consumers in a positive mood decreases the extent to which they will critically review an advertisement's claims, thus increasing its persuasiveness. ${ }^{108}$ As summarized by Jon Hanson and Douglas Kysar, "developing positive affect within consumers with respect to a particular

103. "Parts of the brain" is somewhat of an oversimplification. System 1 and System 2 are not contained in any specific part of the brain. See id. at 29. Nonetheless, different regions of the brain have been associated with different functions in the decisionmaking process. $I d$.

104. Main, supra note 93, at 619-20 (alteration in original) (quoting Zaltman and adding that "this psychological link becomes more important to marketers' strategies than actually making the best product").

105. Id. at 622 n.102; see also Giovanni Vecchiato et al., Neuroelectrical Brain Imaging Tools for the Study of the Efficacy of TV Advertising Stimuli and Their Application to Neuromarketing 101-08 (2013) (discussing how neuromarketing research could be used to evaluate the emotional impact of different frames of a television commercial and revise the ad in order to maximize persuasiveness).

106. See GreEnFELd, supra note 98, at 61 (emphasis omitted) (noting that "the brain scans did a better job of predicting the purchase decision than the subject's own self-reported preferences and price points").

107. Chingching Chang, How Individuals Develop Brand Evaluations in Different Contexts-The Relative Impacts of Affect, Self-Relevant Thoughts, and Product-Attribute Thoughts, 32 ADVANCES Consumer Res. 106, 106 (2005)

108. See Haan, supra note 53, at 1299-1300. 
product or a particular shopping venue can greatly enhance the perceived utility - and significantly lower the perceived risk - that those consumers attribute to the product or the shopping venue." 109 Thus, sophisticated stores manage the environment (the lighting, artwork, music, and so forth) in order to create a positive mood state for consumers and thereby prompt unplanned purchases. ${ }^{110}$ In television advertisements, humor (E-Trade's talking baby, for example) is used to boost the viewer's mood, implant positive associations with the brand, and disarm the viewer's critical faculties. ${ }^{111}$ By contrast, providing more information in advertisements can actually create a negative affect by requiring viewers to spend their mental energy on processing the content. This explains the research finding noted above that research subjects were less likely to select a brand if more information had to be analyzed in order to compare that brand with others. ${ }^{112}$

An additional finding revealed by the dual-processing model is the "mereexposure effect." This is the discovery, well-established in cognitive psychology, that "[s]imply being exposed to something will cause you to like it more." 113 People are typically unaware of this effect, almost never citing prior exposure as a reason for liking an object more. ${ }^{114}$ Nonetheless, this effect operates consistently across different cultures and has even been shown to work when the exposure is not consciously remembered. ${ }^{115}$ The mere-exposure effect is often employed in combination with other marketing techniques geared to create positive affect; in effect, consumers are bombarded with messages associating a product with a positive trait—and the more exposure, the better. The idea is that " $[\mathrm{b}] \mathrm{y}$ pairing the brand name of the product with stimuli that naturally elicit positive emotional responses from people, over many repetitions, consumers learn to associate the brand with positive emotions." 116 As a result,

109. Hanson \& Kysar, supra note 83, at 1445 (emphasis omitted).

110. Id.

111. See Haan, supra note 53, at 1299-1300 ("In other words, a likeable, interesting commercial message creates a positive mood that is associated with the product advertised, and positive mood may interfere with critical analysis of the product's costs and benefits.").

112. Id. at 1298 .

113. Arkush, supra note 94 , at 1310 .

114. $I d$.

115. Id. at 1311; Jochim Hansen \& Michaela Wänke, Liking What's Familiar: The Importance of Unconscious Familiarity in the Mere-Exposure Effect, 27 Soc. Cognition 161, 162 (2009). Hansen and Wänke tested their theory that the mere-exposure effect would be stronger when subjects did not consciously recall exposure. They distracted subjects while showing them fictitiously named pharmaceutical products. Even though the subjects, when later tested, could not recall the products they had seen, they displayed more positive attitudes toward the previously viewed pharmaceuticals when compared to a group that had seen the products without distraction and a control group that had not seen the products. Hansen \& Wänke, supra, at 166-72; see also KAHNEMAN, supra note 95, at 67 (noting that the mere-exposure effect "occurs even when the repeated words or pictures are shown so quickly that the observers never become aware of having seen them").

116. Tamara R. Piety, "Merchants of Discontent": An Exploration of the Psychology of Advertising, Addiction, and the Implications for Commercial Speech, 25 SEattle U. L. Rev. 377, 410 (2001) 
"[w]hen they think of the brand, they will have good feelings about it."

\section{Defining Manipulative Marketing}

The brief review of marketing and psychological research presented above suggests that marketers (1) are most successful when emotional content-not information - is presented to consumers, (2) can carefully craft marketing appeals (using humor and other noninformational techniques) to increase the viewer's/reader's receptivity to the marketing message while disengaging critical faculties, and (3) can influence consumer behavior without consumers being aware of the powerful effect of advertising. The first of these points, as already suggested, undermines the Supreme Court's continued reliance on an informationcentered paradigm of advertising. The latter two points bring into question the Supreme Court's archetype of rational consumers who can logically evaluate the merits of advertising directed toward them. Instead, these marketing strategies suggest that consumers are potentially subject-even without their knowledge - to pervasive cognitive manipulation by advertisers. Such strategies, though they do not eliminate consumers' agency, have the potential to significantly bias the bargaining process between marketers and consumers.

Given the scientific landscape, "manipulative marketing" can be defined as noninformational marketing that seeks to take advantage of consumers' cognitive weaknesses and biases. This term encompasses a wide array of promotional techniques that fall along a continuum relating to their visibility. The most problematic forms of manipulative marketing operate almost entirely outside of consumers' conscious awareness - and are effective for that reason (such as the hidden product placements discussed in section II.C below). By implanting (or triggering) desires in consumers' minds without their conscious awareness, this type of marketing seriously violates consumers' autonomy. ${ }^{118}$ Moreover, this type of advertising, because it is difficult to detect, is nearly impossible for consumers to recognize and guard against. Relatively less problematic is advertising that is more transparent and visible, but nonetheless features nonrational, emotional appeals targeted to the limbic system. Thus, for example, television ads associating beer with attractive women are manipulative in the sense that they associate the product with positive characteristics that it does not in fact possess, drawing upon consumers' deeply felt needs to be seen as sexually attractive and well-liked by others. From the perspective of neuroscience, such sexually charged advertising stimulates the pleasure centers of the brain, causing consumers to seek immediate gratification and thereby making purchases and consumption more likely. ${ }^{119}$ This type of "lifestyle advertising," however

\footnotetext{
(internal quotation marks omitted) (quoting Robert B. Settle \& Pamela L. Alreck, Why They Buy: American Consumers Inside And Out 106 (1986)).

117. Id. (internal quotation marks omitted).

118. Hammer, supra note 9, at 466 ("Coming to have wants and values through a noncognitive process constitutes a significant violation of autonomy.").

119. GREENFIELD, supra note 98 , at 59. The phenomenon has a name: the bikini effect.
} 
misleading, is at least much more apparent; critical viewers can see the technique at work and at least attempt to resist its influence. In between these two points on the continuum are other types of manipulative advertising (such as paying a celebrity to wear a particular brand of shoes) that are visible but often not readily identifiable as promotional.

Although the term manipulative marketing covers a wide range of marketing techniques, it should be emphasized that manipulative marketing is not likely to be "false and misleading" as courts have used that phrase. False and misleading marketing, in the courts' usage, has referred to advertisements that make factually false statements or claims. ${ }^{120}$ Manipulative marketing, by contrast, is by definition noninformational; such marketing cannot be factually true or false, because there is no informational statement to be evaluated for its truth. ${ }^{121}$ The doctrinal status of "false and misleading" commercial speech is clear: it is not entitled to First Amendment protection. The doctrinal status of manipulative marketing, however, is unclear and largely unexplored.

The following section of this Article focuses on examples of manipulative marketing techniques that fall on the more problematic end of the spectrum discussed above. It is worth noting that even the more hidden forms of manipulative marketing are not subliminal. Unlike truly subliminal messages that, for example, flicker on a screen too quickly to be detectable by the human eye, the manipulative marketing practices discussed below are not literally invisible. Instead, with sufficient effort, they could be consciously perceived. But like subliminal messages - which have been held to fall outside of the First Amendment's scope ${ }^{122}$-the primary goal of these marketing practices is to influence

120. See, e.g., United States v. Benson, 561 F.3d 718, 725-26 (7th Cir. 2009) (finding that promotional materials suggesting income taxes could be legally evaded was "false advertising, which may be banned consistent with the First Amendment"); Am. Acad. of Pain Mgmt. v. Joseph, 353 F.3d 1099, 1108 (9th Cir. 2004) (finding that state statute prohibiting physicians from advertising themselves as "board certified" when they were not did not violate the First Amendment, because such advertising would be misleading); Castrol Inc. v. Pennzoil Co., 987 F.2d 939, 949 (3d Cir. 1993) (finding that claims regarding the superiority of Pennzoil products were "literally false" and therefore not protected by the First Amendment)

121. See Daniel Hays Lowenstein, "Too Much Puff": Persuasion, Paternalism, and Commercial Speech, 56 U. Cin. L. REv. 1205, 1232 (1988) ("Informational speech passes the Central Hudson threshold if it is truthful, but is blocked from constitutional protection if it is false or misleading. The Court has never acknowledged that this standard is inapplicable to the large percentage of commercial speech that is neither true nor false.").

122. There are few cases on point, but the few courts to consider the issue have held that the dissemination of subliminal messages is not protected by the First Amendment. See, e.g., Waller v. Osbourne, 763 F. Supp. 1144, 1148 (M.D. Ga. 1991) ("The court . . is convinced that the presence of a subliminal message, whose surreptitious nature makes it more akin to false and misleading commercial speech and other forms of speech extremely limited in their social value, would relegate the music containing such to a class worthy of little, if any, [F]irst [A]mendment constitutional protection."); Vance v. Judas Priest, Nos. 86-5844, 86-3939, 1990 WL 130920, at*25 (Nev. Dist. Ct. Aug. 24, 1990) ("Since subliminal communication does not contribute to dialogue, truth, the free market of ideas, democracy or personal autonomy, it is not really 'speech.' Even in its most basic form, the use of speech presumes that views will be exchanged or that information will be conveyed and understood. However, subliminal messages are not intended to convey information to be consciously understood, 
consumer thought and behavior without conscious reflection or consideration (and likely in a much more effective way than communications that are literally subliminal). Having examples of manipulative marketing in mind may help to illuminate the First Amendment issues at stake and the doctrinal frameworks that courts may apply to such marketing.

\section{EXAMPLES OF MANIPULATIVE MARKETING}

One example of a marketing technique that influences consumers on a nonconscious level is the growing use of "sensory advertising" or "sensory branding," that is, "marketing that engages the consumers' senses and affects their perception, judgment and behavior." ${ }^{23}$ Like other manipulative marketing, at least some forms of sensory marketing are effective in large part because of their subconscious effects on consumers. As marketing professor Aradhna Krishna writes:

From a managerial perspective, sensory marketing can be used to create subconscious triggers that define consumer perceptions of abstract notions of the product (e.g., its sophistication, quality, elegance, innovativeness, modernity, interactivity) - the brand's personality. It can also be used to affect the perceived quality of an abstract attribute like its color, taste, smell, or shape. ${ }^{124}$

Put differently, sensory marketing strategies use the senses in addition to sight - smell, hearing, ${ }^{125}$ touch, ${ }^{126}$ and taste ${ }^{127}$ - to create emotional or psychological bonds between consumers and the product or brand at issue. ${ }^{128}$ Such marketing may be particularly important when the product cannot be differentiated from its competitors on "such functional/rational attributes as price or

they are intended to surreptitiously influence the thought processes of an individual, and ultimately, his behavior.").

123. Aradhna Krishna, An Integrative Review of Sensory Marketing: Engaging the Senses to Affect Perception, Judgment and Behavior, 22 J. Consumer Psychol. 332, 333 (2012) (emphasis omitted).

124. Id. (emphasis added). "Given the gamut of advertisements . . that consumers see every day for the thousands of products that are available in the marketplace, it seems that unconscious triggers, like those appealing to the basic senses, may be a more efficient way to appeal to consumers." $I d$. at 334 .

125. See ZaLtman, supra note 96 , at 64 (discussing that consumers varied time spent in stores depending on the music being played and the "decision to stay in the store longer, or to leave more quickly, happened unconsciously"); Krishna, supra note 123, at 341 ("Ambient sound, such as music heard in hotels, restaurants, retail stores, and supermarkets, can influence consumer mood, actual time spent in a location, perception of time spent, and actual spending. For instance, stereotypically French versus German music has been shown to affect the choice of wine-shoppers bought more French (German) wine when French (German) music was played ....”).

126. See Krishna, supra note 123, at 334 ("Bottles like those for Orangina have adopted shapes and textures that resemble the raw material of the product itself, in this case the orange, to stand out from other products, and also to appeal to consumers' haptic sense.").

127. See Bertil Hultén, Sensory Marketing: The Multi-Sensory Brand-Experience Concept, 23 Eur. Bus. REv. 256, 268 (2011) (discussing how the retailer Whole Foods uses free samples as part of a "multi-sensory brand-experience" for consumers).

128. Id. at 263. 
quality." 129

One form of sensory marketing, the use of scents to impact consumer behavior, has been termed "smellvertising." 130 Spending on scent-related advertising is expected to exceed $\$ 500$ million by $2016 .{ }^{131}$ Scent-related cues are particularly powerful because the sense of smell is wired directly to the limbic system, where it taps into emotions and memories. ${ }^{132}$ Even more so than with other senses, "with scent, your brain responds before you think." 133 The close connection between smell and memory means that a smell (for example, the synthetic, burger-like scent that fast-food companies pump through their vents) can immediately trigger the dopamine rush produced by remembering-and anticipating - eating, buying, or using the product in question. ${ }^{134}$ Even when the association between the scent and product is not obvious, pleasant smells can have a powerful impact on consumer behavior by "enhanc[ing] evaluations of products and stores." 135 For instance, "one experiment carried out in a local clothing store in the Pacific Northwest showed that when 'feminine scents' such as vanilla were sprayed in the women's clothing sections, sales of female apparel actually doubled."136

The First Amendment is unlikely to be a barrier to regulating smellvertising (or other sensory marketing), as it would be extremely difficult to argue that smells are speech for First Amendment purposes. For commercial conduct to come within the First Amendment's purview, there must be an "intent to convey a particularized message" as well as a "likelihood ... that the message would be understood by those who [perceived] it."137 Even assuming that a signature scent is intended to communicate a message-such as "You are in the

129. $I d$.

130. See Chelsea Bush, Is 'Smellvertising'Sabotaging Your Diet?, U.S. News \& World ReP. (Oct. 3, 2012, 1:46 PM), http://health.usnews.com/health-news/blogs/eat-run/2012/10/03/is-smellvertisingsabotaging-your-diet.

131. Michael R. Solomon, The Truth About What Consumers Want 11 (2009).

132. Krishna, supra note 123 , at 338-39; see also id. at 334 (using this connection to emotion and memory, "[m]any upscale hotel chains have adopted signature scents with the hope that the scents will helps [sic] their customers better remember other features of their hotel that they loved, and bring them back").

133. Martin Lindstrom, Buy•ology: Truth and Lies About Why We Buy 147 (2008) (quoting Georgia State University marketing professor Pam Scholder Ellen).

134. Id. at 148 .

135. Krishna, supra note 123 , at 339.

136. LindSTROM, supra note 133, at 147; see also GREENFIELD, supra note 98, at 128-29 ("Some casinos reportedly use 'mood-influencing' aromas, to make us more open to the suggestion that we release our grip on our cash.").

137. Clark v. Cmty. for Creative Non-Violence, 468 U.S. 288, 305 (1984) (internal quotation marks omitted) (quoting Spence v. Washington, 418 U.S. 405, 410-11 (1974)). More abstract, symbolic expression (such as "painting[s] of Jackson Pollock, music of Annold Schöenberg, or Jabberwocky verse of Lewis Carroll") is also protected, but it seems similarly unlikely that smell-related advertising would fall within this category of protected expression. Hurley v. Irish-Am. Gay, Lesbian \& Bisexual Grp. of Bos., 515 U.S. 557, 569 (1995). 
Westin"138 - it seems unlikely that those exposed to the scent would perceive any particularized message. Indeed, scent-based marketing (such as Westin's signature scent) is powerful precisely because customers devote little, if any, conscious thought to it and do not identify it as a form of marketing.

Sensory advertising is presented here merely to elucidate the concept of manipulative marketing, even though restrictions on such advertising are unlikely to be subjected to First Amendment review. Other types of manipulative marketing, however, would be substantially more likely to trigger First Amendment scrutiny. The two examples discussed below-product placements and package coloring-fall within that category ${ }^{139}$ They are by no means the only other forms of manipulative marketing, but they are explored in depth here in order to further clarify the paradigm of noninformational marketing that exploits consumers' cognitive weaknesses and biases.

\section{Product Placement}

Paid product placement in entertainment-in movies, television, Broadway shows, videogames, and other media - is a huge, and rapidly increasing, business. Dozens of specialized agencies are eager to help companies find the ideal placement for their products, and "nearly every major content producer and every major advertiser is now engaged in the practice of product placement." 140 At the same time product placement is becoming more pervasive, it is also becoming more subtle. Researchers have found that product placement that blends into the background or storyline of a program is more effective than the obvious, clunky product pitches that were used in the past-and advertisers are putting this research into practice. ${ }^{141} \mathrm{~A}$ valuable product placement is now

138. See Krishna, supra note 123, at 334 (discussing how numerous hotel chains, including Westin, have adopted signature scents intended to "help[] their customers better remember other features of their hotel that they loved, and bring them back").

139. See Lorillard Tobacco Co. v. Reilly, 533 U.S. 525, 569 (2001) (assuming, but not deciding, that tobacco companies have some cognizable First Amendment interest in the manner in which their products are displayed). Note that although artistic productions are entitled to a higher level of First Amendment protection, the product placements within them would still be considered commercial speech. See Matthew Savare, Note, Where Madison Avenue Meets Hollywood and Vine: The Business, Legal, and Creative Ramifications of Product Placement, 11 UCLA ENT. L. Rev. 331, 370-75 (2004). This is similar to ads within newspapers, which are regulated under the commercial speech standard, not under the stricter scrutiny that applies to restrictions on editorial content. See, e.g., 44 Liquormart, Inc. v. Rhode Island, 517 U.S. 484, 504-14 (1996) (plurality opinion) (applying Central Hudson's intermediate scrutiny to law that restricted price-related advertising for liquor in newspapers); Educ. Media Co. at Va. Tech, Inc. v. Swecker, 602 F.3d 583, 590-91 (4th Cir. 2010) (upholding regulation restricting advertisements for alcohol in college newspapers after utilizing commercial speech standard).

140. Ellen P. Goodman, Stealth Marketing and Editorial Integrity, 85 Tex. L. Rev. 83, 93 (2006).

141. Savare, supra note 139, at 334-35 ("Many agencies are using terms such as "product integration' in lieu of 'product placement' to connote a more exacting, subtle, and persuasive approach to marketing a good. Product Integrators defines 'product integration' as the "seamless weaving of a manufactured product into the storyline of an entertainment production." (footnotes omitted)). It should be noted that the government has also paid television shows to incorporate particular themes in their programming, which-although raising distinct legal issues-is also a troubling and potentially 
defined as "one that fits with the story in such a way as to make us forget that it is there to persuade us." 142 As Ellen Goodman summarizes, "[a]t their best ... product placements will be disguised. The promotional message will melt into nonpromotional plot lines, props, and dialogue, enabling advertisers to build brand equity without interrupting the narrative flow of programming." 143

This type of promotion is potentially manipulative, in that advertisers may be able to influence consumers without consumers even being conscious of this effect. Indeed, this appears to be precisely what advertisers are now aiming for. Marketers are well aware of the lessons of the dual-processing model, which suggests that consumers are easier to persuade when they have not engaged their conscious decisionmaking faculties (System 2). Viewers have learned to critically evaluate any claims made in advertising - which is part of the reason explicit claims are now so rare-but product placement can evade this skepticism by blending undetected into the programming. When cognitive capacities are otherwise engaged in following the flow of the TV show or movie, "the audience is most credulous and least defended against promotional messages."144

Numerous research studies confirm that this embedded messaging can be persuasive. In a 2004 study, for example, children in the United Kingdom were shown two versions of clips of the movie Home Alone. One set of clips included a product placement for Pepsi, while the other set did not. After viewing the clips, the children were given a choice of either Coke or Pepsi. The results were striking:

The control group that had not seen the product placement preferred Coke over Pepsi (58:42), while the group that had viewed the product placement preferred Pepsi $(38: 62) \ldots$ Further, [the authors] found "[n]o difference in choice ... between those who correctly recalled the brand and those who did not, regardless of age, suggesting that explicit memory does not play a significant role in choice." 145

manipulative practice. See generally Ariel Berschadsky, White House Anti-Drug Policy: Statutory and Constitutional Implications, 19 CARdozo ArTs \& ENT. L.J. 183 (2001) (discussing the White House's payments to television programs for broadcasting anti-drug programming).

142. John A. McCarty \& Tina M. Lowrey, Product Integration: Current Practices and New Directions, in The Psychology of Entertainment Media: Blurring the Lines Between Entertainment and Persuasion 17, 22 (L. J. Shrum ed., 2d ed. 2012).

143. Goodman, supra note 140 , at 93 (footnotes omitted).

144. Id. at 111 .

145. Angela J. Campbell, Restricting the Marketing of Junk Food to Children by Product Placement and Character Selling, 39 Loy. L.A. L. Rev. 447, 483 (2006) (alteration in original) (quoting research in Susan Auty \& Charlie Lewis, Exploring Children's Choice: The Reminder Effect of Product Placement, 21 Psychol. \& MARKETING 697, 710 (2004)); see also Eva van Reijmersdal et al., A New Branch of Advertising: Reviewing Factors That Influence Reactions to Product Placement, 49 J. ADVERTISING Res. $429,439-40$ (2009) (reviewing literature on product placement and concluding that product placement influences viewer preferences even when the viewers do not remember having seen the product). 
The authors noted that because children tend to view their favorite shows over and over again, product placement can take advantage of the mere-exposure effect to condition youth to have a positive association with particular brands. This positive "implicit memory" is then triggered by exposure to the product in a store, restaurant, or other setting. ${ }^{146}$

Children are not the only ones vulnerable to the effects of product placement; experiments involving adults have shown similar results. For example, a 2002 study showed college students mock sitcom episodes that included different types of product placement for cookies, candy, ice cream, and soda. ${ }^{147}$ Consistent with the dual-processing model, the study found that "conditions that maximized memory did not necessarily maximize persuasion." 148 Subjects were more likely to remember product placements that were obvious and central to the story line. But in these cases, "viewers tend[ed] to think about the reason for the brand's presence in the show and raise their cognitive defenses," and accordingly, those types of product placement were less effective at persuading viewers. ${ }^{149}$ By contrast, subjects were more likely to be persuaded by product placements that were more subtle and blended into the sitcom's background. Because the products did not seem out of place, they did not appear to be advertising and therefore were not "counterargued" by the viewers. ${ }^{150}$ As in the Pepsi/Coke study, these product placements were effective in influencing viewers' attitudes, even though viewers had no conscious recall of exposure to the products. The study's author recommended to marketers that "instead of negotiating placement arrangements that entail a tight integration of the brand with the plot or mentions in the dialogue," it would be more effective-and cheaper-to "simply try to get the brand to visually appear in the background, without any auditory reference or plot connection."151

146. Campbell, supra note 145 , at 483 .

147. See generally Cristel Antonia Russell, Investigating the Effectiveness of Product Placement in Television Shows: The Role of Modality and Plot Connection Congruence on Brand Memory and Attitude, 29 J. CONSUMER Res. 306, 313-14 (2002).

148. Id. at 313 .

149. Id. at 314; see also McCarty \& Lowrey, supra note 142, at 19-20 ("When consumers recognize a communication as a persuasion attempt, they will process the message differently than if no such recognition occurred. They may get distracted from the message, disengage from the communication, and develop assessments of the persuasion effort and the company related to the communication.").

150. Russell, supra note 147, at 314.

151. Id. For other studies reaching similar results, see, for example, Sharmistha Law \& Kathryn A. Braun, I'll Have What She's Having: Gauging the Impact of Product Placements on Viewers, 17 Psychol. \& Marketing 1059, 1070 (2000) (testing the effect of product placement in a television sitcom and concluding that "[t]he seen-only products were least recalled but most influential on choice, indicating that the facilitative effects of placements might be most influential if they are not consciously accessed"); Moonhee Yang \& David R. Roskos-Ewoldsen, The Effectiveness of Brand Placements in the Movies: Levels of Placements, Explicit and Implicit Memory, and Brand-Choice Behavior, 57 J. Сомм. 469, 483 (2007) (finding that college-age subjects who viewed a product in a movie clip were more likely to select that product as a gift, even without any explicit memory of seeing the product). 
Product placement is particularly problematic when the products at issue are harmful to health - as is the case with fast food, candy, ${ }^{152}$ soda, beer, and cigarettes. ${ }^{153}$ With the exception of the major cigarette companies-who, under the terms of the 1998 Master Settlement Agreement, agreed to stop paying for product placement ${ }^{154}$-companies producing these products are major players in the product promotion industry. Recently, for example, MillerCoors reached an agreement with TNT and TBS providing that characters in original series produced by the network would only drink MillerCoors beers. ${ }^{155}$ Going forward, the bar in the TBS series "Sullivan \& Son" will serve only MillerCoors brands, and the characters in "Dallas" will relax by enjoying Miller Lite. (A Turner Entertainment executive explained the company would find "the natural environment for all the different brands of MillerCoors to place into the shows when appropriate for those episodes," emphasizing that "[t]he last thing we want to do is make it too obvious." ${ }^{156}$ The impact of such agreements on alcohol use has yet to be measured, but numerous studies have shown a surprisingly strong connection between exposure to smoking in movies in early adolescence and smoking behavior in later teen years. ${ }^{157}$

\section{Packaging Color}

Because no one can take the time to carefully consider and analyze each of the thousands of decisions he or she must make each day, people rely on

152. The product placement of Reese's Pieces in E.T. is one of the most iconic and successful product placements of all time. Sales of Reese's Pieces increased by $65 \%$ within a month of the movie's release. Laurie A. Babin \& Sheri Thompson Carder, Advertising via the Box Office: Is Product Placement Effective?, 3 J. Promotion Mgmt. 31, 32 (1996).

153. Tobacco companies were, as with other advertising techniques, at the forefront of developing product placement-even going so far as to as place cigarettes in child-focused movies such as Superman (1978) and The Muppet Movie (1979). In the Superman movies, Lois Lane (who does not smoke in the comic book) puffs away on Marlboros, and Superman "battles his enemies amidst towering Marlboro billboards and ubiquitous Marlboro delivery trucks." Robert Adler, Here's Smoking at You, Kid: Has Tobacco Product Placement in the Movies Really Stopped?, 60 Mont. L. Rev. 243, 244 (1999). In the contract between Philip Morris and the studio producing Superman II, the studio agreed to avoid "any reference in the edited footage of the whole film that might reasonably be construed as detrimental to the Marlboro brand name." Contract Between Dovemead Limited and Philip Morris Europe, S.A. (Oct. 18, 1979), http://legacy.library.ucsf.edu/tid/cxz55e00/pdf.

154. Although the tobacco industry no longer pays for product placement, it may still be giving away free products and effects for use in movies and television. See Matthew S. Fuchs, Comment, Big Tobacco and Hollywood: Kicking the Habit of Product Placement and On-Screen Smoking, 8 J. HEALTH CARE L. \& POL'y 343, 348-49 (2005).

155. E.J. Schultz, The Only Beer in TNT and TBS Shows Now Comes from MillerCoors, AdvERTISING AGE (Mar. 20, 2013), http://adage.com/article/media/millercoors-strikes-product-placement-pact-tnt-tbs/ 240451/.

156. $I d$.

157. U.S. Dep't of Health \& Human Servs., The Health Consequences of Smoking-50 Years of Progress: A Report of the Surgeon General 775 (2014) (describing "a large body of epidemiologic, behavioral, and experimental data" supporting the conclusion that "there is a causal relationship between depictions of smoking in movies and initiation of smoking among young people"); see also id. at 813 (reporting that "those who get the most exposure to onscreen smoking are about twice as likely to begin smoking as those who get the least exposure"). 
heuristics - or mental shortcuts - to help them make decisions quickly and efficiently. ${ }^{158}$ While these heuristics help people to avoid cognitive overload, "when manipulated by researchers or marketers, [they] can also lead to consistently misguided decisionmaking." 159 Packaging color is one product feature that can help consumers to make rapid decisions by signaling the presence or absence of certain attributes. People often make purchasing decisions within seconds of encountering a product, and marketing experts believe that the product's (or its packaging's) color has a significant-if not the dominantimpact on the purchasing decision. ${ }^{160}$ In the retail environment, color can also be used to influence consumer moods, which can have an effect on subsequent purchasing behaviors. ${ }^{161}$

Colors can be used to inform, but because consumers react so strongly and intuitively to colors, they can also be used to mislead. Consider, for example, the use of the color green to signal environmentally friendly products. There has been a considerable amount written about the apparently pervasive practice of "greenwashing," whereby companies make unsubstantiated or misleading environmental claims in order to increase sales or justify higher prices. ${ }^{162}$ Relatively little attention has been paid to the related phenomenon of companies literally making their packaging green in order to signal environmental consciousness. There is emerging evidence, however, that this use of green in packaging can be a deeply misleading way of suggesting a product trait-environmental friendliness - that does not in fact exist. When combined with some other cue that leads consumers to think about the environment (such as the presence of trees or a textual prompt), use of the color green primes consumers to assume that the product is environmentally friendly. For instance, a series of studies conducted by marketing professor Joon Yong Seo showed that "consumers perceive products with an environmental claim as environmentally superior when their packages are in green rather than in red." 163 In his experiments, consumers perceived the green products to have a more positive environmental impact, even when the packaging for the product made no such claim and simply referenced the environment. ${ }^{164}$ Interestingly, consumers who were more concerned about environmental protection were most vulnerable to this cogni-

158. Jon D. Hanson \& Douglas A. Kysar, Taking Behavioralism Seriously: The Problem of Market Manipulation, 74 N.Y.U. L. REv. 630, 662 (1999).

159. Hanson \& Kysar, supra note 83 , at 1433.

160. Satyendra Singh, Impact of Color on Marketing, 44 MGmT. Decision 783, 783 (2006).

161. Id. at 785 (noting, for example, that "red color stimulates appetite because of its effect on our metabolism, making red a popular color choice among fast-food restaurants").

162. See TerraChoice, The Sins of Greenwashing: Home and Family Edition 6 (2010), available at http://sinsofgreenwashing.org/index35c6.pdf (finding that 95\% products labeled as "green" included claims that were either misleading or unsubstantiated).

163. Joon Yong Seo, The Role of Color in Environmental Messages and Claims: Green Can Be Both Beneficial and Misleading 66 (Aug. 2010) (unpublished Ph.D. dissertation, University of Utah), http://content.lib.utah.edu/utils/getfile/collection/etd2/id/230/filename/1830.pdf.

164. Id. at 71. In Seo's experiment, the product labeling stated that the company supported an environmental group, not that the product was itself environmentally friendly. 
tive bias, perhaps because the color green triggered a stronger emotional affinity in such customers. ${ }^{165}$

Factually misleading or inaccurate claims can be regulated by the Federal Trade Commission (FTC), which maintains a "Green Guide" to provide businesses with guidance on acceptable environment-related claims. ${ }^{166}$ But in line with the FTC's general position that its regulatory purview is limited to claims that affirmatively present false or misleading information, the Green Guide says virtually nothing about the misleading use of color. ${ }^{167}$ It is not clear the extent to which the misleading use of green packaging is a problem, but to the extent it is, it appears to meet the definition of manipulative marketing set forth above. The color green, when used to inaccurately convey environmental concern, conveys no actual information (or, if anything, inaccurate information). At the same time, it has a powerful effect on consumer choices, particularly for environmentally conscious shoppers, because the association of the color green with environmentalism is a heuristic used (essentially subconsciously) to facilitate faster and easier decisionmaking.

Tobacco packaging provides a second example of how color can be deployed in a manipulative way: the color on the packaging is used to convey misleading impressions of reduced risk. Despite the fact that "light" and "low tar" cigarettes are no safer than "regular" cigarettes, the tobacco companies spent decades marketing these products as less harmful alternatives to full-flavor cigarettes. ${ }^{168}$ In 2009 , Congress prohibited tobacco companies from using the terms "light," "low tar," and "mild," on cigarette packages, but the companies responded (in the United States, as well as in other countries where such descriptors have been restricted) by using color coding to perpetuate false perceptions relating to health risk. ${ }^{169}$ Thus, for example, cigarettes that were previously Marlboro Ultra Lights are currently sold as Marlboro Silver, with the lighter color of the box used to suggest that the product is safer than other brands. ${ }^{170}$

Since well before 2009 , tobacco companies have been aware that pack color and pack design can convey an impression of reduced risk. Tobacco industry documents show that "[a] wide range of colour and design configurations were

165. Id. at 72 .

166. See 16 C.F.R. § 260.1-.17 (2014). The Green Guide, first issued in 1992, reflects the FTC's current views about which environmental claims are unfair or deceptive under the FTC Act. $I d$. $\S 260.1$ (a).

167. For example, the guide uses a hypothetical example of an advertisement for a printer that features pictures of a forest and states "Buy our printer. Make a change" in green font. 16 C.F.R. $\S 260.4(d)$ ex. 3 (2014). The guide suggests that this would improperly suggest an environmental benefit (unless there is evidence to support such a benefit), even though there is no express claim made regarding the printer's environmental impact. The guide does not discuss packaging that may use color and/or images to similarly convey a misleading impression in the absence of any such slogan.

168. United States v. Philip Morris USA, Inc., 449 F. Supp. 2d. 1, 560 (D.D.C. 2006).

169. U.S. Dep't of Health \& Human Servs., Preventing Tobacco Use Among Youth and Young Adults: A Report of the Surgeon General 599-600 (2012).

170. See id. at $531-32$. 
market tested with consumers to determine designs that most led consumers to perceive that the cigarettes in the pack were 'mild' or lower in strength." ${ }^{171}$ Internal documents from Philip Morris and R.J. Reynolds show that both companies reached the identical conclusion that by lightening colors and images, and by increasing the amount of white space on the packages, they could convey an impression that some brands were less potent than others. ${ }^{172}$ Moreover, in addition to the tobacco company documents, independent research studies demonstrate that package colors continue to be incredibly persuasive in conveying misleading impressions of reduced health risk. For example, in a 2009 study with more than 600 participants, $79 \%$ of respondents believed that a cigarette pack with lighter blue shading would pose less of a health risk than an identical pack with darker blue shading. ${ }^{173}$ Similarly, packages with white symbols were rated as posing lower risks than those that used grey. ${ }^{174} \mathrm{~A}$ study conducted in the United Kingdom likewise concluded that "[t]he colour of packs was ... associated with false beliefs about tar delivery and health risk: packs with lighter colours were rated as less harmful and easier to quit." ${ }^{175}$ These studies found that all types of consumers were misled, regardless of age and smoking status. ${ }^{176}$

Both of these examples_-involving "green" packaging and cigarette labelingappear to be cases of the emotional "old brain" overruling the "new brain." Even though one could rationally conclude that the color of packaging does not control the safety, quality, or other attributes of the product inside, it seems clear that many (if not most) people do not reach that conclusion. Instead, people are misled, mostly subconsciously, by the associations created by the packaging. ${ }^{177}$ Green, at least for a significant subset of consumers, triggers a connection to environmentalism, which, as some researchers have shown, is often a deeply emotional connection. ${ }^{178}$ Even when this environmental benefit is nonexistent,

171. M. Wakefield et al., The Cigarette Pack as Image: New Evidence from Tobacco Industry Documents, 11 Tobacco Control 73, 76 (2002).

172. Id. at $76-77$.

173. David Hammond \& Carla Parkinson, The Impact of Cigarette Package Design on Perceptions of Risk, 31 J. Pub. Health 345, 348 (2009).

174. Id. at 350 .

175. David Hammond et al., Cigarette Pack Design and Perceptions of Risk Among UK Adults and Youth, 19 Eur. J. Pub. Health 631, 635 (2009).

176. See Crawford Moodie et al., A Brief Review of Plain Packaging Research for Tobacco PRODUCTs (2009).

177. This is one reason that Australia has now mandated "plain packaging" for tobacco products that prohibits color variation and allows only the product's name in standardized font (in addition to a health warning). Demonstrating the power of product branding, smokers in Australia have complained that cigarettes sold in plain packaging taste worse than branded cigarettes, and they report that all cigarette brands now taste the same. Long-Term Smokers Find Plain-Packaged Cigarettes Taste Worse, GuARDIAN (July 14, 2014, 11:14 PM), http://www.theguardian.com/society/2014/jul/15/smokers-find-plainpackaged-cigarettes-taste-worse.

178. Patrick Hartmann \& Vanessa Apaolaza Ibáñez, Green Value Added, 24 Marketing IntelligenCE \& Planning 673, 676 (2006) (discussing evidence that people buy "green" products largely because such purchases make people feel better about themselves). 
consumers may still pay a premium for packaging suggesting an environmental link. Likewise, the lighter color on tobacco packaging impacts risk assessments, apparently because of widely shared subconscious and emotional associations with lighter colorings (although the effect may also be due, at least in part, to the industry's historical marketing of "light" cigarettes).

Although the issue is not well developed in case law, courts seem to presume that color is a characteristic of advertising protected by the First Amendment. In 2012, the Sixth Circuit struck down a provision in the Family Smoking Prevention and Tobacco Control Act that would have barred the use of color and graphics in most tobacco advertising (but not product packaging). ${ }^{179}$ The court ruled that the restriction was overbroad because " $[a] l l$ use of color and imagery in tobacco advertising, of course, is not deceptive or manipulative." 180 The court instructed the government that "[i]nstead of instituting a blanket restriction on color and graphics in tobacco advertising, the government may instead restrict only the speech necessary to effect its purposes." suggested that the use of color was protected (to some unspecified degree) under the First Amendment, but at the same time, it recognized that the government could limit uses of color that were demonstrably manipulative.

\section{THE NONSOLUTION OF DISCLOSURE REQUIREMENTS}

When the problem of manipulative marketing is raised, increased disclosure - or other forms of consumer education - is typically considered the appropriate governmental response. The discussion of the dual-processing model above, however, demonstrates why this response is inherently deficient: manipulative marketing is used precisely because emotive and nonconscious messaging is more effective than the straightforward presentation of information typically employed in mandated disclosures. Disclaimers may serve to point out the use of manipulative marketing practices, but they do not necessarily undermine their effectiveness. Even presuming that such disclaimers are feasible, it is likely that consumers would either (1) perceive disclaimers as intrusive and annoying, or (2) ignore them, thereby undermining their value.

The existing disclosures required for product placement in broadcast television programming are a case in point. Section 508 of the Communications Act "imposes criminal penalties on broadcast employees, program suppliers, and sponsors for failure to disclose sponsorship." 182 These disclosures, however, are buried in the rapidly scrolling small print of the closing credits and are therefore almost never noticed by viewers. Viewers increasingly avoid watching the closing credits altogether because "they have shut off the television, changed

179. Disc. Tobacco City \& Lottery, Inc. v. United States, 674 F.3d 509, 548 (6th Cir. 2012), cert. denied, 133 S. Ct. 1996 (2013).

180. Id. at 547 (emphasis added).

181. Id. at 548 .

182. Goodman, supra note 140 , at 96 (discussing 47 U.S.C. $\$ 508$ ). 
the channel, closed the browser window or changed browser tabs . . . or watched the show through a DVR (which often cuts off the credits)." 183 Even if they see the disclaimers, the one sentence of scrolling text is unlikely to undo whatever impressions were created by the product placement. ${ }^{184}$ Indeed, when the product is subtly placed in the program's background, consumers are unlikely to recall having seen the product, even with the aid of a disclaimer. ${ }^{185}$ Scientific studies further show that the subconscious effect of the mereexposure effect cannot be undone with a disclaimer. ${ }^{186}$ By contrast, when product placements are acknowledged or obvious, a disclaimer serves no purpose - and indeed is not required by the Communications Act-because consumers are already aware of the information that would be disclosed.

Due to these weaknesses in the current disclaimer regime, some have called for disclaimers of paid product placements to be identified when they occurthrough "pop-up disclosures" that hover above the program's content, or through a crawl line at the bottom of the screen. ${ }^{187}$ These proposed cures, however, may not be tolerated by viewers. Unless they dissuaded producers from using any product placements, pop-up disclosures would be intrusive and distracting, making it difficult for viewers to connect with and enjoy the programming. ${ }^{188}$ Pointing out the embedded content would put into motion consumers' "cognitive defenses," causing them to critically analyze the advertisers' attempts at persuasion and distracting them from the content of the program. This might well help to undermine the manipulative potential of product placement-but the annoyance is likely more than most viewers would be willing to accept.

A crawling disclosure at the bottom of the screen suffers from the same liabilities. If viewers pay attention to the crawler, they are likely to experience an "information interference effect" that inhibits their ability to process the content of the programming. ${ }^{189}$ But if viewers learn to tune out the crawling

183. Zahr Said, Embedded Advertising and the Venture Consumer, 89 N.C. L. REv. 99, 158 (2010).

184. See id. at 157-58 (noting that because of the "primacy effect," consumers may discount the disclaimers because the product placement has already influenced their attitudes).

185. The disclaimer regime of the Communications Act suffers from numerous other weaknesses. Among others, it applies only to original programming for broadcast TV and does not cover product placement in movies that were originally released in theaters. Moreover, it does not cover cases where the products are provided to the studios for free, but no additional payments are made. $I d$. at $135 \mathrm{n} .169$.

186. Angela Y. Lee, The Mere Exposure Effect: Is It a Mere Case of Misattribution?, 21 ADVANCES CONSUMER Res. 270, 274 (1994) ("[T]he mere exposure effect cannot be undone by knowledge of prior exposure."). In addition, disclaimers are of course an ineffective way of informing children who cannot understand them. See Keith A. Gorgos, Straightforward Information Sold Separately: Why Current Regulation Fails to Adequately Protect Children from Deceptive and Unfair Advertising, $14 \mathrm{~J}$. ТЕСH. L. \& PoL'y 107, 131 (2009).

187. Said, supra note 183 , at 140 . The FTC denied the request for additional disclosure, stating that in the absence of factually false statements, "consumer injury from an undisclosed paid product placement seems unlikely." Campbell, supra note 145, at 458-60.

188. Cf. Said, supra note 183 , at 150 (describing viewers' legitimate interest in "remaining engaged in entertainment content without intrusions or involuntary interruptions").

189. Sheree Josephson \& Michael E. Holmes, Clutter or Content? How On-Screen Enhancements Affect How TV Viewers Scan and What They Learn, 2006 Proc. Ass'n for Computing Machinery Symp. 
disclaimers altogether - as seems likely to occur-then the disclaimers are rendered useless. Moreover, the form of the disclaimer nearly ensures its ineffectiveness. Static text simply cannot compete with the subconscious, emotional attachment to products and brands that product placement is intended to cultivate. ${ }^{190}$ This is another case where the affective "old brain" is likely to overrule the logical and deliberative "new brain."

The same general principles hold for disclaimers on colored packaging or other forms of manipulative marketing; factual disclaimers are unlikely to act as an effective counterweight. Such informational efforts, despite their intuitive appeal, are generally ineffective at influencing behavior. ${ }^{191}$ This is not because the public responds "irrationally to the truth," 192 to use the Supreme Court's phrase, but because factual disclaimers do not operate in a vacuum. The marketplace-of-ideas metaphor underlying the Supreme Court's commercial speech doctrine assumes the presence of competing ideas. But the metaphor breaks down when disclaimers expressed in plain text must compete against advertising techniques that rely on noninformational, nonconscious, and emotional appeals. ${ }^{193}$ Factual statements versus manipulative advertising is not a fair fight. ${ }^{194}$ Policymakers are therefore left with two realistic options: they can either prohibit some forms of manipulative marketing, or they can allow the status quo to continue.

The preceding discussion is not meant to suggest that regulation is always the appropriate response to manipulative advertising. There are several reasons to exercise caution before pursuing a regulatory response. For one, consumers may

on Eye Tracking Res. \& Applications 155, 161 (finding that a crawling headlines aided recall only when they were congruent with the program's content, and otherwise diminished recall).

190. See PIETy, supra note 7, at 118 (discussing the limited power of information in the face of advertising that, among other techniques, "uses emotional symbolism and manipulation of cognitive biases or blind spots").

191. Parmet \& Smith, supra note 45, at 377 ("Although little doubt exists that individuals can make decisions based upon information that they directly receive, controlled studies have failed to show significant efficacy of public health campaigns premised on this pathway. It turns out that the simple act of conveying information to an individual seldom suffices to change that individual's behavior." (footnote omitted)).

192. Thompson v. W. States Med. Ctr., 535 U.S. 357, 375 (2002) (internal quotation marks omitted) (quoting 44 Liquormart, Inc. v. Rhode Island, 517 U.S. 484, 503 (1996)).

193. Ignoring this dynamic, the D.C. Circuit Court of Appeals recently struck down the FDA's proposed graphic warnings for cigarette packages and advertisements. These warnings could be seen as Congress's attempt to "fight fire with fire," that is, to respond to the tobacco industry's own noninformational, lifestyle advertising with more visually and emotionally powerful counter-messaging. The circuit court ruled that because the proposed warnings were "not "purely' factual" and were instead "primarily intended to evoke an emotional response," they were subject to heightened scrutiny and were invalid. R.J. Reynolds Tobacco Co. v. Food \& Drug Admin., 696 F.3d 1205, 1216-17 (D.C. Cir. 2012).

194. This may explain why anti-tobacco ads are effective at keeping adolescents from smoking only when they are not also exposed to pro-tobacco advertising. When adolescents are exposed to both anti-tobacco and pro-tobacco advertising, "anti-tobacco media exposure [does] not mitigate the harmful effects of the pro-tobacco media." Jie Wu Weiss et al., Longitudinal Effects of Pro-Tobacco and Anti-Tobacco Messages on Adolescent Smoking Susceptibility, 8 Nicotine \& Tobacco Res. 455, 462 (2006). 
be willing to accept manipulative marketing as part of an implicit trade-off for other benefits. Some survey research suggests that "respondents prefer[] product integrations to traditional advertisements ... [because] advertisements are perceived as intrusive and annoying, whereas the unobtrusive nature of product integrations make them more palatable to consumers." 195 Moreover, product placements in both media and retail stores are important sources of revenue. In the media context, product placements help underwrite programming, thereby making more shows available to consumers. ${ }^{196}$ Likewise, in the retail environment, payments for product placement generate revenue that allows businesses to offer discounts.

Even in the absence of offsetting benefits, any regulatory scheme would face exceedingly difficult challenges in trying to distinguish manipulative marketing from nonmanipulative marketing, especially given the still-evolving state of psychological and neuromarketing research. Additionally, regulations could unfairly burden businesses (if overbroad), introduce unfairness in the marketplace (if unevenly enforced), or produce unintended consequences (if they push advertisers toward different forms of manipulative marketing). ${ }^{197}$ Thus, the doctrinal question of whether manipulative marketing may be regulateddiscussed in the following Part-should be kept distinct from the regulatory policy question of whether such marketing should be regulated in any particular case.

\section{Manipulative Marketing MeEts the First Amendment}

The Supreme Court has never reviewed the constitutionality of regulating noninformational commercial speech, such as the examples discussed above. This is, in short, unexplored doctrinal space. The conventional wisdom suggests that regulations of noninformational marketing would be invalidated by the courts in accordance with the Supreme Court's increasing scrutiny of limits on commercial speech. However, the more nuanced analysis set forth in Part I reveals the Court may be open to restrictions on manipulative marketing. Indeed, its cases-starting with Virginia Pharmacy and continuing through 44 Liquormart and even Sorrell-have suggested that when the government's goal is to ensure the fairness of the bargaining process by, for example, protecting consumers from manipulation, the courts' review should be deferential. These

195. McCarty \& Lowrey, supra note 142, at 27.

196. Said, supra note 183, at 152. Reliance on product placement as a funding mechanism, however, tends to skew the nature of programming. It leads to programming written with product placements in mind, and it discourages the development of content that might offend potential sponsors.

197. Because of the risk of unintended consequences inherent in command-and-control regulation, Ryan Calo recently proposed two creative options for regulating potentially manipulative marketing that do not rely on prohibiting specific types of advertisements: (1) a "paid-option regime," in which media providers would be required to offer consumers the option of paying to opt out of marketing altogether, and (2) "[c]onsumer [s]ubject [r]eview [b]oards," through which companies would internally review the possible manipulative effects of marketing on consumers, applying preestablished principles. Ryan Calo, Digital Market Manipulation, 82 GEo. WASH. L. Rev. 995, 1045-48 (2014). 
hints that regulation of manipulative marketing practices might be sanctioned, however, have not been fully developed.

Accordingly, this last section explores how the Supreme Court's doctrine, explained in Part I, could respond to regulations of manipulative marketing practices like those explored in Part II. Freed of the assumption that advertising is informational, the Court could either: (1) deem manipulative practices unprotected by the commercial speech doctrine, or (2) take a less drastic approach and apply intermediate scrutiny as defined by the Central Hudson test. This latter approach has several distinct advantages over the former, and, crucially, it would allow for the Central Hudson test to be applied in a manner than is not "fatal in fact." As described in this section, applying the Central Hudson test to manipulative marketing provides a framework for allowing the government to curb manipulative advertising practices when there is sufficient proof that manipulative practices are undermining the government's legitimate interests in public health and individual well-being.

\section{A. EXCLUDING MANIPULATIVE MARKETING FROM FIRST AMENDMENT PROTECTION}

Given that the commercial speech doctrine is predicated on the now-outdated construct of informational advertising, one could argue that noninformational commercial speech is not entitled to First Amendment protection at all. The three justifications offered by Virginia Pharmacy for protecting commercial speech were that such speech (a) provides needed information to individuals, (b) helps to facilitate efficient decisionmaking in the marketplace, and (c) may include discussion of issues of public interest. If not one of these three justifications applies to manipulative marketing, why should it be protected? Thus, one way that the Court's commercial speech doctrine could respond to manipulative marketing is by recognizing it as a type of communication wholly unprotected by the First Amendment, just as false or misleading commercial speech can be restricted without the need for any further analysis. ${ }^{198}$

Manipulative marketing is characterized not only by a lack of informational communication, but also by the attempt to undermine consumer autonomy by taking advantage of their cognitive limitations and biases. When this latter characteristic of manipulative marketing is in play, the justification for constitutional protection is considerably weakened. The rationales provided in Virginia

198. This is, in a rough sense, the doctrinal approach that has been applied by the Supreme Court of Canada, which applies a commercial speech analysis similar to the Central Hudson test. Micah L. Berman, Commercial Speech Law and Tobacco Marketing: A Comparative Discussion of the United States and Canada, 39 AM. J. L. \& MED. 218, 225-31 (2013). In Canada v. JT1-MacDonald Corp., the Supreme Court of Canada upheld a law that permitted "informational" tobacco advertisingadvertising about a product's characteristics, availability, or price - but barred lifestyle tobacco advertising that "associates a product with ... a way of life such as one that includes glamour, recreation, excitement, vitality risk or daring." Canada (Att'y Gen.) v. JTI-MacDonald Corp., [2007] S.C.R. 610, para. 28 (Can.). Such "lifestyle" advertising, the Court held, does not further the "values protected by the free expression guarantee: individual self-fulfillment, truth seeking and democratic participation." Id. para. 34 . 
Pharmacy all rely on consumers evaluating the information provided and making their own, autonomous decisions. But manipulation is, by definition, the opposite of free choice and reasoned decisionmaking. It is instead the exercise of power over malleable consumers. ${ }^{199}$ Without disregarding the role of individual responsibility in decisionmaking, it is apparent that manipulative marketing can powerfully influence consumers' choices-to the extent that what appear to be, and feel like, autonomous and unprompted decisions are often influenced and orchestrated by marketers without any consumer awareness. ${ }^{200}$ In the product placement experiments discussed in Part II for example, the subjects believed they were making wholly independent choices (about Coke v. Pepsi, for example) and did not realize the extent to which their choices were influenced by subtle product placement. At the economy-wide level, these marketing techniques may "lead[] to our being less autonomous insofar as we unthinkingly follow the patterns of behavior, modes of self-expression and identity, and even rebellion defined for us in part by advertisers."201 Rather than fostering dissent and debate-two hallmarks of First Amendment theorymanipulative marketing constitutes the exercise of "unregulated power" over consumer decisionmaking. ${ }^{202}$

Additionally, the scholarship of "critical realists" such as Jon Hanson and David Yosifon would suggest that so long as manipulative marketing is unregulated, marketplace actors must either engage in such conduct or be driven from the market. ${ }^{203}$ As Yosifon writes, "in the same way that market forces compel firms to devise and employ the most efficient forms of business organization," competitive pressures will push corporations to use effective forms of marketing, even if those methods take advantage of consumers' cognitive limitations. $^{204}$ Indeed, businesses may not even realize that they are employing manipulative marketing techniques, but they must mimic their competitors' use of such practices if they wish to survive. ${ }^{205}$ Because competing firms will be

199. See C. Edwin Baker, The First Amendment and Commercial Speech, 84 InD. L.J. 981, 991 (2009) (writing that "exercises of power of one person over another should be subject to collective regulation while exercises of persuasion ... almost never should be").

200. See GREENFIELD, supra note 98, at 134 ("From the standpoint of marketers, the perfect product is one that is purchased out of habit or compulsion, but which the purchaser feels he or she has exercised free will and rationality in choosing.").

201. Piety, supra note 116, at 421 (footnotes omitted). This has long been the ultimate goal of product advertising. One of modern advertising's early innovators, Edward Bernays, coined the term "engineering of consent" in the early twentieth century in order to emphasize that "the illusion of agency was a critical component of the consumer culture." Allan M. Brandt, The Cigarette Century 87-88 (2007).

202. Baker, supra note 199 , at 995.

203. See David G. Yosifon, Resisting Deep Capture: The Commercial Speech Doctrine and JunkFood Advertising to Children, 39 Loy. L.A. L. Rev. 507, 512-19 (2006) (explaining "critical realism").

204. Id. at 518 .

205. Id. (writing that because the market "reward[s] with profit firms that [engage in manipulative practices] and render[s] bankrupt those that do not, corporations may come to engage in manipulative situational influence vis-à-vis consumers even without any human beings within the corporation consciously desiring to do so"). 
driven by competitive markets toward using similar marketing practices, "we cannot expect that [companies] will expose the transmission of implicit and emotional messages, something they themselves do." ${ }^{206}$ In this sense, the case for the government regulating manipulative marketing is even stronger than the case for regulating misleading or false advertising, which is already excluded from First Amendment protection. The marketplace of ideas may help to unmask false or misleading promotions, but it is less likely to alert consumers to manipulative ones.

Outside the context of commercial speech, the Supreme Court has held that speech that forms "no essential part of any exposition of ideas" can be restricted without First Amendment review. ${ }^{207}$ As Yoav Hammer and Tamara Piety have separately argued, the categories of unprotected speech in the Court's First Amendment doctrine largely correspond to areas where the type of speech does not allow for a reasoned and deliberative response from the listener. As Piety writes:

[O]ne construction of what the Court has done is to determine that [unprotected] speech does not appeal to rational faculties either because it inspires an emotional (fighting words) or 'animalistic' response (obscenity) or because it may rely on feeding false information into the rational thought process (false or misleading commercial advertising and libel). ${ }^{208}$

Manipulative marketing is, by definition, calculated to elude rational processing by the listener, and it thus fits logically alongside these other categories of unprotected speech. The justification for leaving false and deceptive advertising outside of the First Amendment's protection applies with (at least) equal force to manipulative advertising. As Hammer summarizes:

A false/deceptive advertisement is a manipulation of information, which we prohibit in order to assure that people would be able to deal with expressions rationally. If we follow this rationale, we must conclude that the manipulation involved in the transmission of implicit and emotional messages in advertisements should likewise not be allowed. ... [T] here is no reason to believe that people deal with the implicit and emotional messages in advertisements better than they deal with false and deceptive advertisements. ${ }^{209}$

Indeed, consumers are likely better able to respond to false or misleading statements than they are to manipulative messages, particularly ones they do not

206. Hammer, supra note 9 , at 491.

207. Chaplinsky v. New Hampshire, 315 U.S. 568, 572 (1942).

208. Piety, supra note 116, at 406; see also Hammer, supra note 9, at 482 ("[F]reedom of expression facilitates certain desired objectives: Correction of errors and attainment of truth through the marketplace of ideas, realization by individuals of their capacity for autonomy, realization of the democratic idea of self-rule by the public. However, only speech which allows for deliberation of the listeners can facilitate these objectives.").

209. Hammer, supra note 9, at 490-91. 
consciously perceive. As Part II revealed, people are generally skeptical of explicit marketing communications and discount factual claims made in marketing. It is for that reason that marketers are increasingly turning to tools such as sensory marketing and subtle product placements in order to evade that skepticism. $^{210}$

Although the case for adding manipulative marketing as a new category of unprotected speech has some strong appeal, it is also has several-likely fatal-drawbacks. First, as explained in Part II, manipulation is a matter of degree and hence it may be difficult to build consensus on types of marketing that are indeed manipulative (or manipulative to a problematic extent). Particularly when advertising contains both emotive and informational elements, the line between manipulative and nonmanipulative marketing may be exceedingly hard to draw. Second, although the Supreme Court has left some categories of speech, like obscenity, without First Amendment protection despite the absence of clear lines, it seems unlikely that the Supreme Court-which has been wary of adding new categories of unprotected speech $^{211}$ —would adopt the categorical approach. In the recent case of United States v. Alvarez, for example, the Court declined to recognize "false statements" (outside of the commercial context) as a new category of unprotected speech, writing that categorical exclusions from First Amendment protection are generally limited to the "few historic and traditional categories [of expression] long familiar to the bar."212 Third, even though Sorrell dealt with the straightforward provision of information, dicta in the decision stating that "impressive endorsements or catchy jingles" are protected speech suggests that the Court sees at least some types of noninformational "puffery" as falling within the First Amendment's commercial speech protections. ${ }^{213}$

210. See Horwitz, supra note 2, at 60 ("If the regulation of commercial speech is to serve the function of guarding against the significant effects that advertising can have on consumers, then a bolder hand should be taken against misleading speech, and a broader understanding of that term should be encouraged.").

211. See, e.g., United States v. Stevens, 559 U.S. 460, 472 (2010) (declining to recognize "depictions of animal cruelty" as unprotected speech).

212. 132 S. Ct. 2537, 2544 (2012) (alteration in original) (internal quotation marks omitted) (quoting Stevens, 599 U.S. at 468 ).

213. Sorrell v. IMS Health Inc., 131 S. Ct. 2653, 2671 (2011). What the Supreme Coutt meant by this passage is somewhat unclear. Endorsements and jingles-though not necessarily informationalcan be methods of communicating information. The Court did not clarify whether it was the endorsements and jingles themselves that were entitled to First Amendment protection, or only the information they communicated. The puffery doctrine has been largely developed outside of the First Amendment context. It is based on the notion that consumers will disregard claims that are obviously exaggerations. But as David Yosifon notes:

The idea that statements constituting puffery do not influence consumer behavior or decisionmaking is given the lie by the fact that a substantial proportion of contemporary advertising consists of nothing but puffery. If puffery were as inconsequential as the puffery doctrine holds it to be, then profit-maximizing corporations would not engage in it . . . .

Yosifon, supra note 203, at 532-33. 
More fundamentally, given the way the marketing environment (and our understanding of the psychology of decisionmaking) has evolved, it may make sense to extend constitutional protection beyond the mere provision of factual information. Most advertising is designed to appeal to emotions and not solely to reason. Indeed, nearly all advertising is emotive in the limited sense that the seller is trying to express enthusiasm for the product and generate the desire to purchase it. Even if such emotional advertising is unavoidably manipulative in some respects, it may not be valueless. As David Arkush writes, "Given limited human capacities for information processing and reasoning, it seems likely that non-linguistic and emotional forms of communication may be desirable in some instances." 214 People communicate not just through the straightforward transmission of information, but through music, stories, humor, and subtle cues. A legal doctrine that broadly stripped all such advertising of First Amendment protection would constitute a dramatic break with the status quo. Thus, excluding noninformational marketing from any constitutional protection may be too blunt a tool; it would risk chilling protected speech (such as advertisers genuinely beaming about the positive effects of their products) and depriving marketers of any compelling method of communicating truthful information.

\section{B. INTERMEDIATE SCRUTINY}

As opposed to a categorical rule, the Central Hudson test may provide a workable analytical framework for evaluating restrictions on manipulative marketing. ${ }^{215}$ This approach has several key advantages over a categorical rule. First, it recognizes that emotional advertising is not inherently valueless and that regulating manipulative marketing requires weighing competing interests. Thus, rather than leaving manipulative marketing with no constitutional protection, it instead requires that regulations pass intermediate scrutiny. Such scrutiny ensures that the government can provide evidence that the speech at issue is indeed harmful and manipulative and that the regulation at issue is not overbroad.

Second, this approach has the advantage of utilizing the standard that the Supreme Court (at least formally) still applies to commercial speech cases. And unlike the current application of the Central Hudson test, when applied to manipulative marketing practices this approach should not be fatal in fact. As explained in Part I, the Central Hudson test has proven fatal to government restrictions on commercial speech because-despite its claim to balance interests - the Court has not left any room, regardless of the importance of the government interests, for restrictions that deprive consumers of information. The Court's cases suggest, however, that advertising that subverts the fairness

214. Arkush, supra note 94 , at 1359.

215. If one considered manipulative marketing to be misleading under the first prong of the Central Hudson test, then the Central Hudson test could serve to operationalize the categorical rule discussed above. When intermediate scrutiny is discussed in this section, it presumes that the Central Hudson test would not be applied in this manner. 
of the bargaining process may more easily survive scrutiny. ${ }^{216}$ When the government acts to protect consumers from manipulation (rather than to restrict the provision of information), the Central Hudson test would not be fatal in fact, and instead it could help courts strike a balance between consumer protection and freedom of speech. When addressing a restriction on manipulative marketing, the existing Central Hudson test might be applied as follows.

\section{To Qualify for First Amendment Protection, the Commercial Speech Must Concern Lawful Activity and Not Be Misleading}

Being wary of cutting off its analysis at this early stage, the Court has essentially equated "misleading" with factually false, never halting its review of a restriction on commercial speech after consideration of only this prong. ${ }^{217}$ As previously noted, manipulative marketing would not fall within the category of "false or misleading" speech when defined in this way. The Court should clarify that what it is really looking for at this stage of the analysis is speech that is factually false or related to illegal activity - which will rarely be the case for manipulative marketing. ${ }^{218}$ This approach best reflects the Court's actual practice and ensures that restrictions on manipulative marketing will be given careful, not cursory, review. ${ }^{219}$

\section{The Government's Asserted Interest in Restricting the Speech Must Be Substantial}

As the discussion in Part I suggests, the courts are skeptical of attempts to regulate nonmisleading informational advertising in order to further governmental goals such as the protection of public health. But the calculus may change when noninformational, manipulative marketing is at issue. The courts have consistently held public health to be a significant (even compelling) governmental interest for purposes of the second prong of the Central Hudson test. ${ }^{220}$

216. See, e.g., supra text accompanying notes $57-58$.

217. Although this conflation of terms (essentially replacing the word "misleading" with "false") is confusing, the doctrinal approach is logical, once one accepts the Court's skeptical stance with respect to commercial speech regulations. In addition, because the cases presented to the Supreme Court have mostly involved truthful commercial speech, the Court has been able to avoid squarely addressing this question of what exactly "misleading" marketing means. Piety, supra note 116, at 391.

218. As Christopher Robertson suggests, it may be "category mistake" for courts to even ask whether noninformational speech is truthful or not; the question presumes that the communication can be categorized as true or false. Christopher Robertson, When Truth Cannot Be Presumed: The Regulation of Drug Promotion Under an Expanding First Amendment, 94 B.U. L. REv. 545, 559 (2014).

219. But see Samantha Graff et al., Government Can Regulate Food Advertising to Children Because Cognitive Research Shows That It Is Inherently Misleading, 31 Health AFr. 392, 395-96 (2012) (arguing that any advertising directed to young children should fail the first prong of the Central Hudson test). Advertising to children presents a set of different issues not explored in this Article.

220. Samantha Rauer, When the First Amendment and Public Health Collide: The Court's Increasingly Strict Constitutional Scrutiny of Health Regulations That Restrict Commercial Speech, 38 Aм. J.L. \& MED. 690, 702-03 (2012) ("The Court . . . has never struck down a public health regulation 
Restrictions on commercial speech intended to further that goal have foundered instead on the fourth prong of the test because the Court has found restricting (informational) commercial speech to be an overly restrictive and paternalistic means of pursuing that interest. When manipulative marketing techniques are being restricted, however, the government can argue that its goal is to protect consumers from manipulation, not (as Sorrell and other cases have accused the government of doing) to paternalistically manipulate consumer decisions itself.

Thus, when seeking to address manipulative marketing, the government's interest could be characterized as protecting public health (or other substantial state interests, such as public safety or environmental protection) by preventing consumers from being manipulated into harmful actions. Framed in this manner, the government's goal—unlike in cases where the Court has struck down restrictions on commercial speech-is not to prevent the distribution of information about harmful products; rather, it is to ensure that consumer decisions about harmful products are autonomous and not the product of manipulation. This hybrid governmental interest in protecting health and preventing manipulation $^{221}$ provides the government with a stronger probability of passing through the last two prongs of the Central Hudson test. ${ }^{22}$

Additionally, this hybrid interest is likely to be an accurate reflection of what the government's interest truly is. Particularly given the risks and potential downsides of regulation, regulators and legislators may not care if marketing practices are manipulating consumer decisionmaking, so long as the products

because the related government interest cannot pass the second prong of Central Hudson. The protection of public health ... is usually successfully defended as being a substantial government interest."). Some lower courts have begun to question whether the government can ever assert a substantial interest in restricting truthful, nonmanipulative commercial speech. See, e.g., Disc. Tobacco City \& Lottery, Inc. v. United States, 674 F.3d 509, 535 (6th Cir. 2012) ("[A] State's paternalistic assumption that the public will use truthful, nonmisleading commercial information unwisely ... will not support a finding of a substantial state interest." (internal quotation marks omitted) (quoting 44 Liquormart, Inc. v. Rhode Island, 517 U.S. 484, 497 (1996))); Nat'l Ass'n of Tobacco Outlets, Inc. v. City of Worcester, 851 F. Supp. 2d 311, 316 (D. Mass. 2012) ("[Plaintiffs] contend that the City has no legitimate interest in prohibiting non-misleading advertising to adults to prevent them from making decisions of which the City disapproves. I agree.").

221. Like the interest in public health, the interest in preserving the fairness of the consumer exchange is also clearly a substantial government interest. See, e.g., 44 Liquormart, 517 U.S. at 501 (plurality opinion) ("When a State regulates commercial messages to protect consumers from misleading, deceptive, or aggressive sales practices, or requires the disclosure of beneficial consumer information, the purpose of its regulation is consistent with the reasons for according constitutional protection to commercial speech and therefore justifies less than strict review."); Edenfield v. Fane, 507 U.S. 761, 768 (1993) (recognizing substantial government interest in preventing "fraud and other forms of deception"); In re R. M. J., 455 U.S. 191, 203 (1982) (recognizing a substantial government interest in preventing inherently misleading advertising or advertising proven "subject to abuse"). Therefore, the hybrid interest proposed above should qualify as a substantial government interest. See Pearson v. Shalala, 164 F.3d 650, 656 (D.C. Cir. 1999) (acknowledging "that the government's interest in preventing consumer fraud/confusion may well take on added importance in the context of a product, such as dietary supplements, that can affect the public's health").

222. See Main, supra note 93, at 634-37. Under Central Hudson review, the Court will not "supplant the precise interests put forward by the State with other suppositions." Fla. Bar v. Went For It, Inc., 515 U.S. 618, 624 (1995) (quoting Edenfield, 507 U.S. at 768). 
themselves are not dangerous, harmful, or otherwise causing negative secondary effects. If manipulative practices are being used to promote one brand of detergent over another, there is probably little cause for concern, despite the violation of consumer autonomy that may be involved. In such a case, governmental intervention would likely cause as many or more problems as it solved. However, where the products involved are contributing to significant health, safety, or environmental problems, there is a stronger argument for government intervention. For example, the promotion of soda is intended in large part to develop and solidify brand preferences, but the overall impact of such promotion is to increase the use of products that significantly contribute to diabetes and other chronic diseases. When manipulative marketing practices are being used to promote soda consumption, the government has two reasons to intervene: to protect public health and to protect consumers from manipulation.

\section{The Restriction Must Directly Advance the Government's Asserted Interest}

If the government's interest is defined as protecting public heath ${ }^{223}$ by preventing consumers from being manipulated, then the government must be able to prove both that (a) the product or activity being promoted is harmful, and (b) the advertising at issue is manipulative. The first part of this test should be relatively simple to demonstrate using product analyses, epidemiological evidence, and the like. The second part could be shown with the types of evidence discussed above: psychological experiments, neuromarketing research, marketing studies, and so forth. Importantly, government should not be required to show that the proposed restriction on marketing would in fact improve public health. Rather, the government need only show that the marketing technique is manipulative in the sense that it takes advantage of consumers' cognitive biases and limitations. The purpose of the regulation would then be to unbias consumer decisions, which would hopefully_but not necessarily-improve healthrelated outcomes. Going further, and requiring the government to affirmatively show an impact on public health, would suggest that the government was seeking to paternalistically manipulate consumer decisions in a particular direction. Instead, it should be sufficient for the government to show that the regulation furthers its interest in allowing consumers to make autonomous and independent choices, even if many of those consumers do not ultimately make healthy choices. ${ }^{224}$ In the example of color-coded cigarette packages, for instance, the goal of a regulation would be to ensure that consumers were not mislead into selecting cigarettes they erroneously believed to be less hazardous.

223. Public health is used here as a stand-in for other substantial government interests such as environmental protection and public safety.

224. Restricting manipulative marketing will not leave consumer decisions totally autonomous. Decisions are influenced by innumerable factors in society: friends, media, culture, etc. As the Court's commercial speech doctrine recognizes, however, there is a significant distinction between commercial and noncommercial influences, and the government has a legitimate interest in ensuring that businesses do not use their commercial power to take advantage of consumers. 
Although a change in packaging might induce some smokers to quit, the courts should evaluate whether the measure directly advances the primary objective of redressing manipulation — not whether it increases smoking cessation.

\section{The Restriction Must Not Be More Extensive Than Necessary to Serve the Asserted Government Interest}

This fourth prong has been the one on which most commercial speech restrictions have failed. The Supreme Court has suggested that the provision of more information (public education or disclosures) is always preferable to restrictions on informational speech. ${ }^{225}$ In the context of manipulative marketing, however, a restriction on such marketing should restrict little, if any, actual information from being disseminated - and preferably none at all. Rather, it should narrowly target marketing practices that seek to manipulate consumer decisions without providing any actual information. If the greenwashing of packaging was found to manipulate consumer decisions, for example, the regulation should target only the color of the packaging (not any associated content), and only the specific types of packaging where manipulation was shown to be a problem. A regulation that broadly prohibited producers from using green packaging would be far too overbroad.

Narrowed in this way, such restrictions on manipulative marketing are entirely consistent with the purpose of the commercial speech doctrine. Moreover, as previously discussed, attempts to unbias consumers exposed to manipulative marketing by providing them with disclaimers or additional information are likely to be futile and therefore would not constitute suitable alternatives. ${ }^{226}$ Accordingly, the government should have the burden of establishing that the restriction at issue restricts only manipulative marketing, and no other types of marketing. If the government can make this showing, the regulation should be upheld.

$$
* * * *
$$

Despite the usefulness of this four-part test, it still leaves many questions unanswered. For one, clarifying what type of proof is sufficient to show manipulation will be a challenge. As discussed previously, manipulative marketing practices lie on a continuum. Some such practices are visible and, at least in theory, could be recognized and resisted by consumers. Others are more hidden, and their influence is much more difficult to detect. Should manipulation be measured by the cognitive effort required to identify and consider the advertising technique? By the percentage of people who are misled? At what point

225. Thompson v. W. States Med. Ctr., 535 U.S. 357, 371 (2002) ("[W]e have made clear that if the Government could achieve its interests in a manner that does not restrict speech, or that restricts less speech, the Government must do so.").

226. This is another point at which the government's asserted interest (prong two) is relevant. If the interest is to reduce consumption of a harmful product, then non-speech-related means (taxation, price regulation, sales restrictions, etc.) may be available. If the goal is to restrain manipulative marketing, however, these non-speech-related approaches are not suitable alternatives. 
should a marketing practice that misleads some, but not all, consumers be deemed manipulative?

Another remaining question is how the courts will assess the "fit" between a regulation and the joint interest in protecting public health and preventing manipulation. One potential approach might be for courts to balance both the manipulative character of the marketing and the harmfulness of the product in considering whether a restriction is overbroad (prong four). If a form of advertising is particularly manipulative (imagine subliminal messages that are shown to be incredibly effective), perhaps regulation is justified by the violation of consumer autonomy, even in the absence of significant harms. By contrast, perhaps if a product is particularly dangerous - as in the case of cigarettes, which are both addictive and deadly-marketing restrictions can be supported even when the advertising at issue is less manipulative (presuming it is still manipulative to some degree).

Courts will have to develop answers to these and many other key questions over time, and such a process is likely to take decades. But despite the imprecision and ambiguity of the Central Hudson test (weaknesses shared by most other legal tests), it appears to be the framework that best protects First Amendment interests while ensuring that the government can still act effectively to protect against real harms. The test ensures that as little commercial speech as possible is restricted. Only speech that is demonstrably harmful and manipulative can be restricted, and regulations that are overbroad will be struck down.

\section{Conclusion}

For more than three-and-a-half decades, the Supreme Court has built its commercial speech doctrine around an informational paradigm. In the Court's cases, commercial advertising is assumed to be primarily informational, and its unfettered dissemination is presumed to further First Amendment values precisely because it communicates information. But this doctrinal foundation is shaky. A huge percentage of commercial speech is not informational. Quite intentionally, marketers are forgoing informational appeals and instead turning to advertising that connects with consumers on a nonconscious, emotional level. These communications are designed to influence consumers, but not convince them. The advertising is designed to build a connection to a brand, not a rational argument.

As these marketing practices continue to evolve, it will become harder and harder for the courts to ignore the growing disconnect between doctrine and reality. Further, the increased use-or misuse - of neuromarketing and sensory marketing research to influence consumers at a nonconscious level is likely to prompt calls for regulation. This will produce opportunities to reconsider the trajectory of the Court's commercial speech cases and to contemplate new doctrinal approaches such as those suggested here. 